OAK RIDGE
NATIONAL LABORATORY

MANAGED BY UT-BATTELLE FOR THE DEPARTMENT OF ENERGY

\title{
Properties of Bulk Sintered Silver As a Function of Porosity
}

Andrew A. Wereszczak, * Daniel J. Vuono, Hsin Wang, and Mattison K. Ferber Materials Science and Technology Division

Zhenxian Liang

Energy and Transportation Science Division National Transportation Research Center

* Corresponding Author wereszczakaa@ornl.gov

Publication Date: June 2012

Prepared by the OAK RIDGE NATIONAL LABORATORY

Oak Ridge, Tennessee 37831

managed by

UT-BATTELLE, LLC

for the

U.S. DEPARTMENT OF ENERGY

Under contract DE-AC05-00OR22725

பT-BATTELLE 


\section{DOCUMENT AVAILABILITY}

Reports produced after January 1, 1996, are generally available free via the U.S. Department of Energy (DOE) Information Bridge:

Web site: $h$ ttp://www.osti.gov/bridge

Reports produced before January 1, 1996, may be purchased by members of the public from the following source:

National Technical Information Service

5285 Port Royal Road

Springfield, VA 22161

Telephone: 703-605-6000 (1-800-553-6847)

TDD: $703-487-4639$

Fax: 703-605-6900

E-mail: info@ntis.fedworld.gov

Web site: http://www.ntis.gov/support/ordernowabout.htm

Reports are available to DOE employees, DOE contractors, Energy Technology Data Exchange (ETDE) representatives, and International Nuclear Information System (INIS) representatives from the following source:

Office of Scientific and Technical Information

P.O. Box 62

Oak Ridge, TN 37831

Telephone: 865-576-8401

Fax: 865-576-5728

E-mail: reports@osti.gov

Web site: http://www.osti.gov/contact.html

This report was prepared as an account of work sponsored by an agency of the United States Government. Neither the United States government nor any agency thereof, nor any of their employees, makes any warranty, express or implied, or assumes any legal liability or responsibility for the accuracy, completeness, or usefulness of any information, apparatus, product, or process disclosed, or represents that its use would not infringe privately owned rights. Reference herein to any specific commercial product, process, or service by trade name, trademark, manufacturer, or otherwise, does not necessarily constitute or imply its endorsement, recommendation, or favoring by the United States Government or any agency thereof. The views and opinions of authors expressed herein do not necessarily state or reflect those of the United States Government or any agency thereof. 


\section{TABLE OF CONTENTS}

\section{Page}

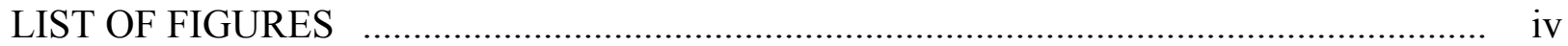

LIST OF TABLES

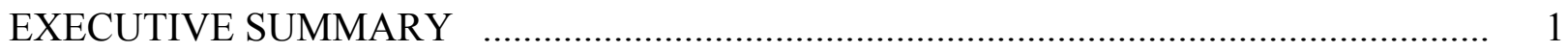

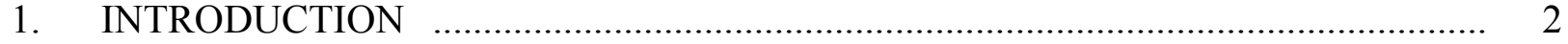

2. EXPERIMENTAL PROCEDURES F.............................................................. 3

2.1. Fabrication of Bulk Silver .............................................................................. 3

2.1.1. Description of Silver Pastes $\quad$.............................................................. 3

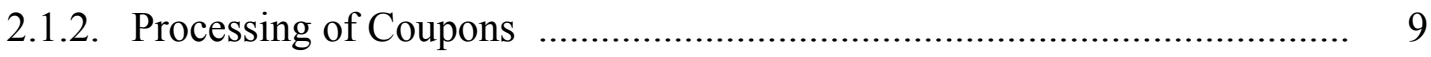

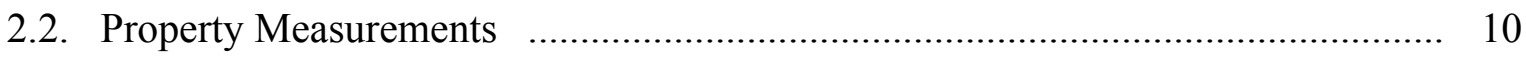

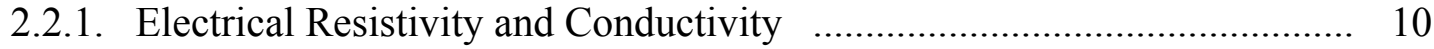

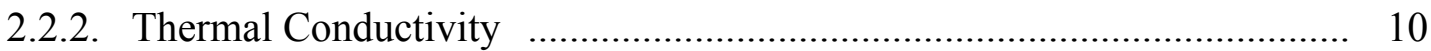

2.2.3. Coefficient of Thermal Expansion ................................................... 11

2.2.4. Elastic Modulus and Poisson's Ratio .................................................. 11

2.2.5. Yield Stress ................................................................................. 11

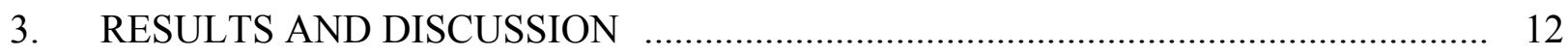

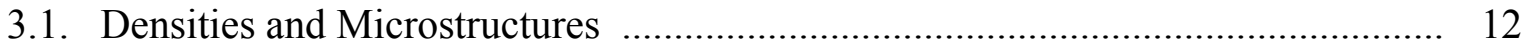

3.2. Property Measurements ............................................................................. 14

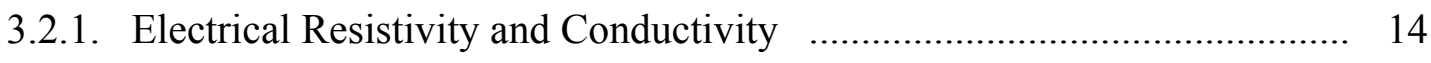

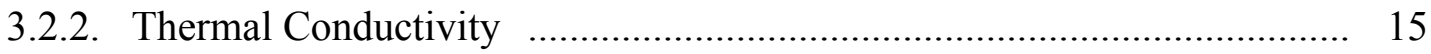

3.2.3. Coefficient of Thermal Expansion .................................................. 16

3.2.4. Elastic Modulus and Poisson's Ratio ................................................ 16

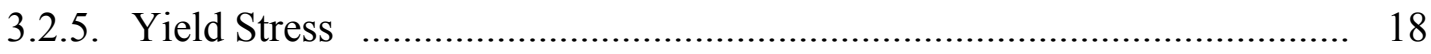

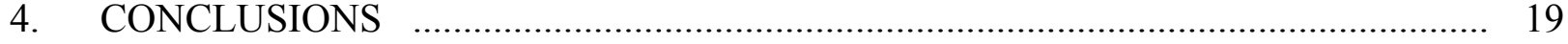

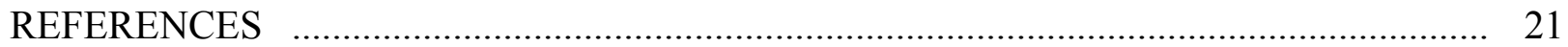

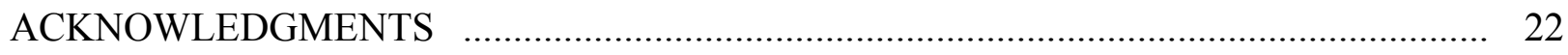

APPENDICES: Silver Paste Manufacturer Technical Literature .................................... 23 


\section{LIST OF FIGURES}

Figure

Page

1. Differential scanning calorimetry (DSC) of C1075S silver paste. . ............................. 4

2. Thermogravimetric analysis (TGA) of $\mathrm{C} 1075 \mathrm{~S}$ silver paste. ................................... 4

3. Differential scanning calorimetry (DSC) of LF131 silver paste. . .............................. 5

4. Thermogravimetric analysis (TGA) of LF131 silver paste. ..................................... 5

5. Differential scanning calorimetry (DSC) of LTS016 silver paste. ............................ 6

6. Thermogravimetric analysis (TGA) of LTS016 silver paste. ...................................... 6

7. Differential scanning calorimetry (DSC) of LTS043 silver paste. . ............................ 7

8. Thermogravimetric analysis (TGA) of LTS043 silver paste. ................................... 7

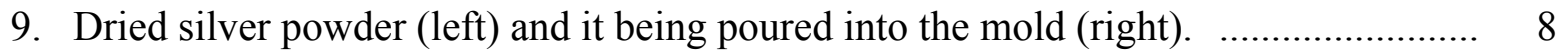

10. Assembled heating system (left) ready for pressure-assisted sintering and a schematic drawing of its structure (right). ...................................................... 9

11. Examples of processed bulk silver coupons. ...................................................... 9

12. Example of a focused ion beam (FIB) milled trench. .......................................... 13

13. Structures formed by FIB milling as a function of porosity. .................................. 13

14. Electrical resistivity $(\rho)$ as a function of porosity and temperature. ......................... 14

15. Electrical conductivity $(\sigma)$ as a function of porosity and temperature. $\ldots . . . \ldots \ldots \ldots \ldots . . . . . . . .15$

16. Thermal conductivity $(\kappa)$ as a function of porosity and temperature. $\ldots \ldots \ldots \ldots \ldots \ldots \ldots . . . . . . . . . .16$

17. Coefficient of thermal expansion (CTE) as a function of porosity. ......................... 17

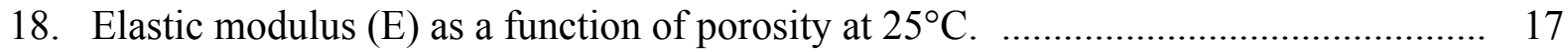

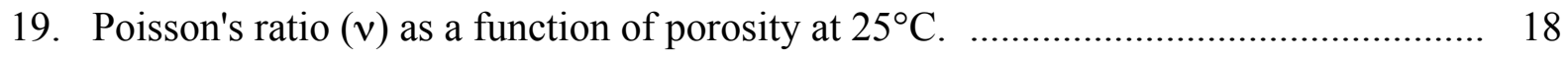

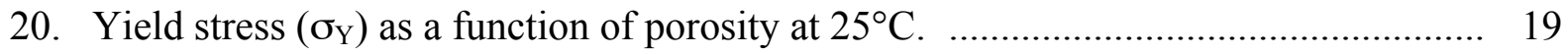




\section{LIST OF TABLES}

Table

Page

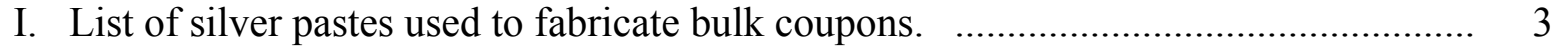

II. Processing conditions and produced silver bulk densities. .................................... 12 


\section{EXECUTIVE SUMMARY}

This report summarizes a study where various properties of bulk-sintered silver were investigated over a range of porosity. This work was conducted within the National Transportation Research Center's Power Device Packaging project that is part of the DOE Vehicle Technologies Advanced Power Electronics and Electric Motors Program. Sintered silver, as an interconnect material in power electronics, inherently has porosity in its produced structure because of the way it is made. Therefore, interest existed in this study to examine if that porosity affected electrical properties, thermal properties, and mechanical properties because any dependencies could affect the intended function (e.g., thermal transfer, mechanical stress relief, etc.) or reliability of that interconnect layer and alter how its performance is modeled.

Disks of bulk-sintered silver were fabricated using different starting silver pastes and different sintering conditions to promote different amounts of porosity. Test coupons were harvested out of the disks to measure electrical resistivity and electrical conductivity, thermal conductivity, coefficient of thermal expansion, elastic modulus, Poisson's ratio, and yield stress.

The authors fully recognize that the microstructure of processed bulk silver coupons may indeed not be identical to the microstructure produced in thin (20-50 microns) layers of sintered silver. However, measuring these same properties with such a thin actual structure is very difficult, requires very specialized specimen preparation and unique testing instrumentation, is expensive, and has experimental shortfalls of its own, so the authors concluded that the herein measured responses using processed bulk sintered silver coupons would be sufficient to determine acceptable values of those properties.

Almost all the investigated properties of bulk sintered silver changed with porosity content within a range of 3-38\% porosity. Electrical resistivity, electrical conductivity, thermal conductivity, elastic modulus, Poisson's ratio, and yield stress all depended on the porosity content in bulk-sintered silver. The only investigated property that was independent of porosity in that range was coefficient of thermal expansion. 


\section{INTRODUCTION}

Silver sintering for interconnection of die to substrates and substrates to heat sinks in power electronic components is an attractive joining alternative to soldering because silver sintered joints have a higher temperature capability, higher thermal conductivity, and are more mechanically resilient. They have been studied for over 10 years [e.g., 1-6], and while their development continues to address a myriad of pending issues, sintered silver joints are starting to be used in some commercial power electronic modules such as the SKiM and SKiiP modules made by Semikron (Nuremberg, Germany).

Sintered silver joints contain porosity. The sintering process, a solid-state diffusional process, typically involves pressure-assistance; however, fully dense sintered silver interconnects do not result. Up to a few tens of percent of porosity seem typical and have been reported [2-3]. Additionally, lower applied pressures for sintering are continually being sought, so resulting porosity content in these sintered joints are likely to be higher yet. For example, Göbl [4] estimated porosity to range between $5-20 \%$ when the pressure used in sintering was varied. It is logical to conclude that the porosity for "no-pressure" sintering could be higher yet than $20 \%$.

Interest existed to examine if the amount of porosity affected electrical properties, thermal properties, and mechanical properties because any dependencies could affect the intended function (e.g., thermal transfer, mechanical stress relief, etc.) or reliability of that interconnect layer and alter how its performance is modeled.

Lastly, the authors fully recognize that the microstructure of processed bulk silver coupons may indeed not be identical to the microstructure produced in thin (20-50 microns) layers of sintered silver. Measuring these same properties with such a thin actual structure is non-trivial, requires very specialized specimen preparation and unique and non-standardized testing instrumentation and test methods [7], and has experimental shortfalls of its own [2]. The authors concluded that the herein measured responses using processed bulk sintered silver coupons would be sufficient to determine acceptable values of those properties. 


\section{EXPERIMENTAL PROCEDURE}

A description of the silver pastes, their consolidation into disk billets, and descriptions of the methods used to measure electrical, thermal, and mechanical properties are presented.

\subsection{Fabrication of Bulk Silver}

\subsubsection{Description of Silver Pastes}

Four different silver pastes were acquired and used to make bulk sintered silver coupons. ${ }^{1}$ They are listed in Table I. Three of the pastes are manufactured by Heraeus and the fourth by DuPont. The two "LTS" Heraeus pastes were developed specifically for sintering.

Table I. List of silver pastes used to fabricate bulk coupons.

\begin{tabular}{|c|c|}
\hline Brand Name & Manufacturer \\
\hline C 1075 S & W. C. Heraeus GmbH, Hanau, Germany \\
\hline LF131 & DuPont, Research Triangle Park, NC USA \\
\hline LTS 016 & W. C. Heraeus GmbH, Hanau, Germany \\
\hline LTS 043 & W. C. Heraeus GmbH, Hanau, Germany \\
\hline
\end{tabular}

Mass loss as a function of temperature was studied in all four pastes using thermogravimetric analysis (TGA), and endothermic or exothermic responses were examined using differential scanning calorimetry (DSC). Their results are illustrated in Figs. 1-8.

\footnotetext{
${ }^{1}$ Reference herein to any specific commercial company, product, process, or service by trade name, trademark, manufacturer, or otherwise, does not necessarily constitute or imply its endorsement, recommendation, or favoring, and shall not be used for advertising or product endorsement purposes.
} 


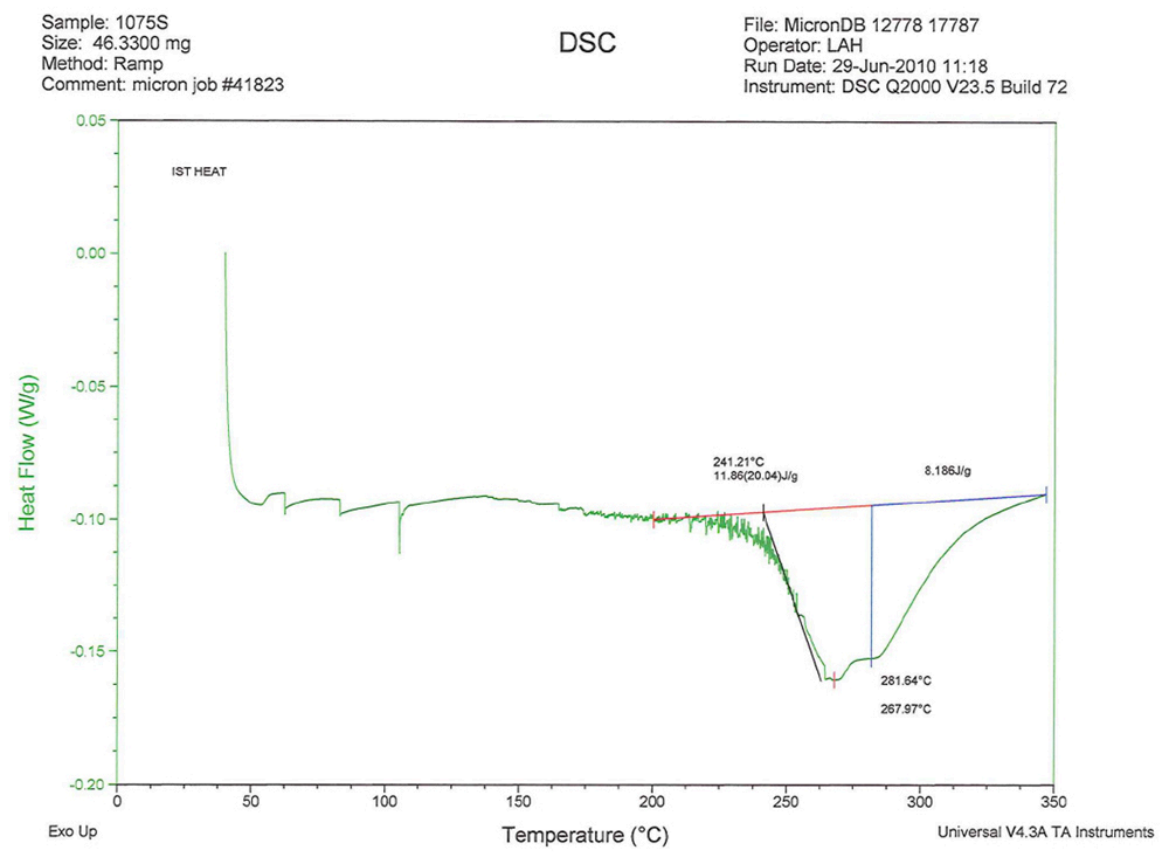

Figure 1. Differential scanning calorimetry (DSC) of C1075S silver paste.

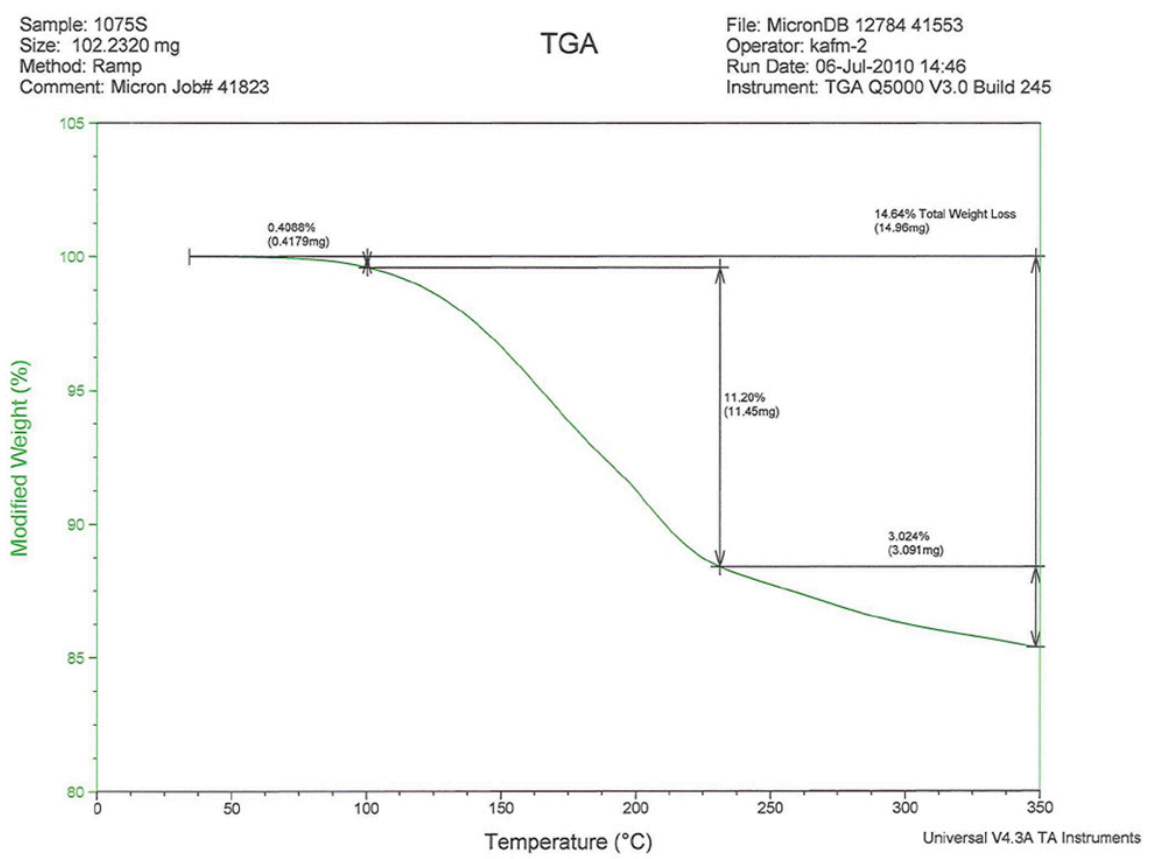

Figure 2. Thermogravimetric analysis (TGA) of C1075S silver paste. 


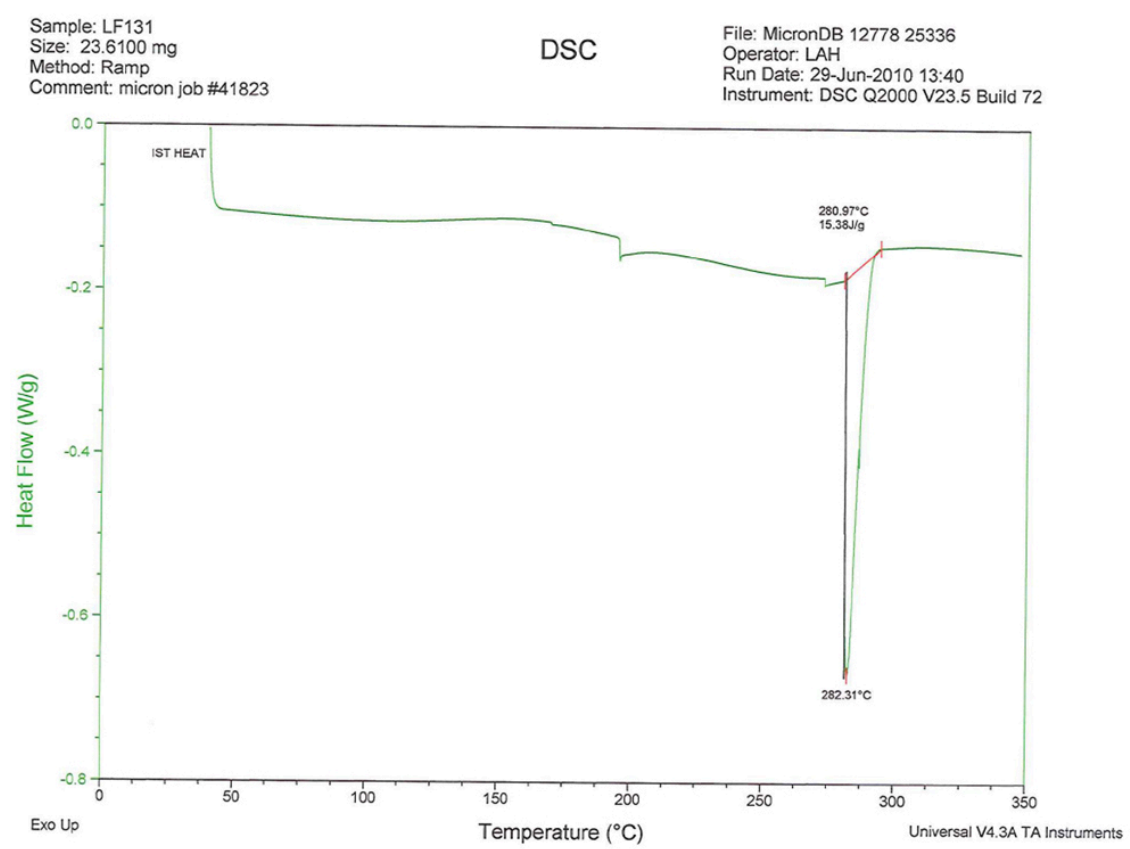

Figure 3. Differential scanning calorimetry (DSC) of LF131 silver paste.

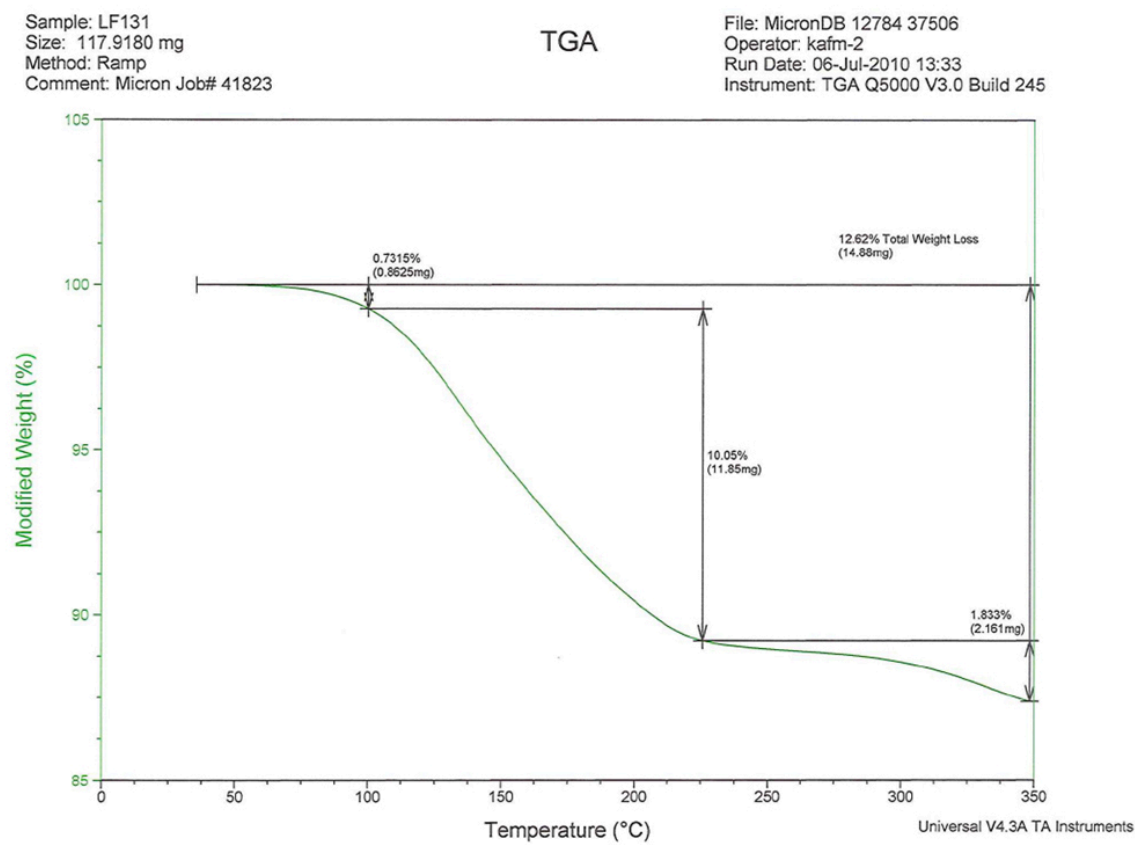

Figure 4. Thermogravimetric analysis (TGA) of LF131 silver paste. 


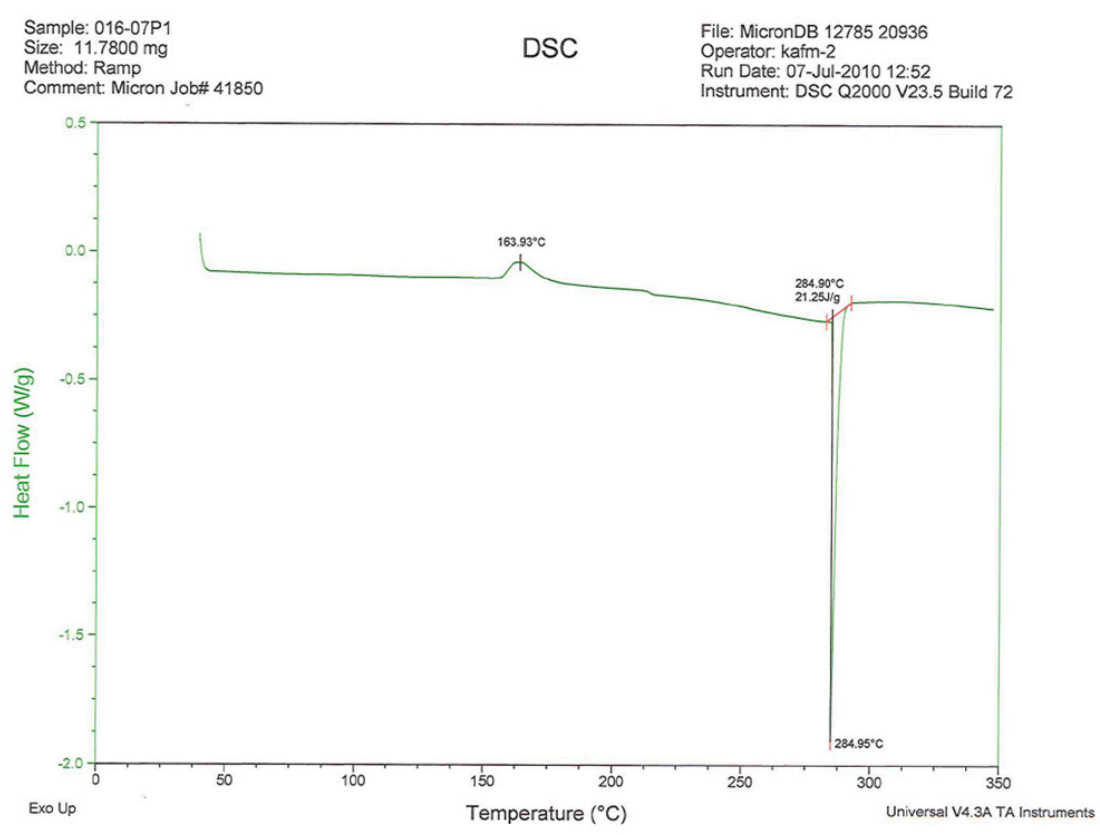

Figure 5. Differential scanning calorimetry (DSC) of LTS016 silver paste.

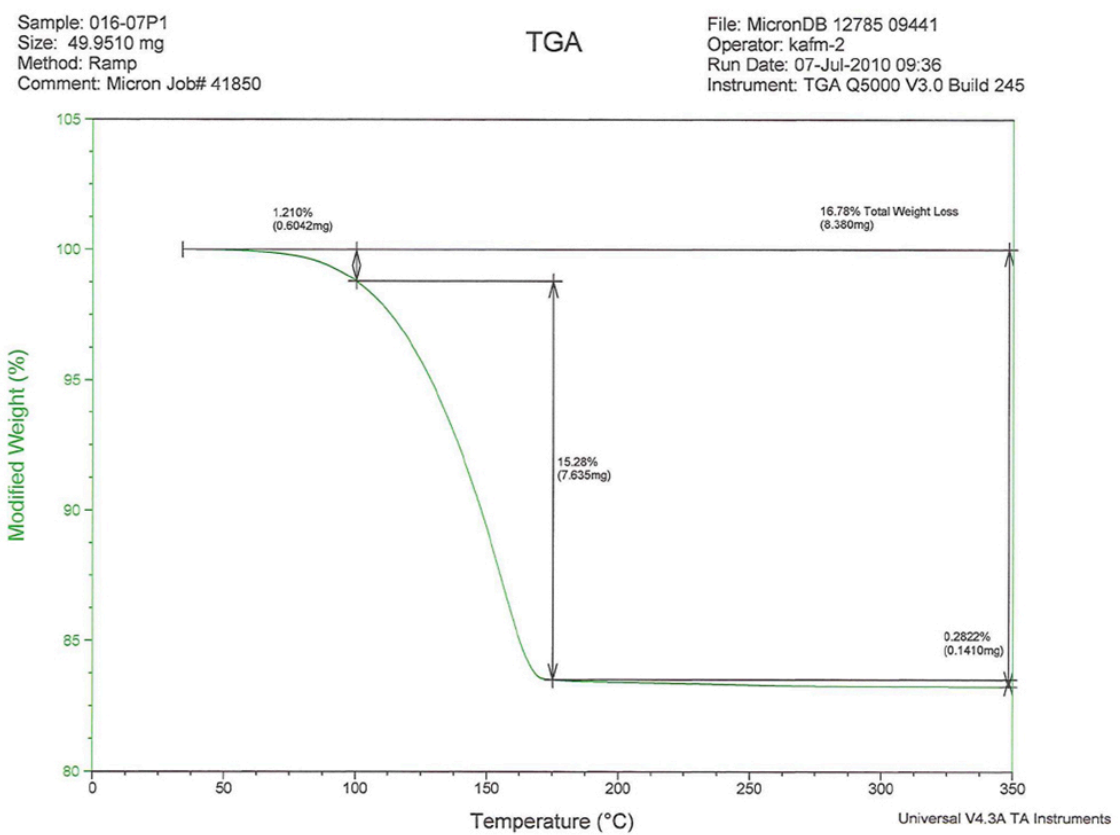

Figure 6. Thermogravimetric analysis (TGA) of LTS016 silver paste. 


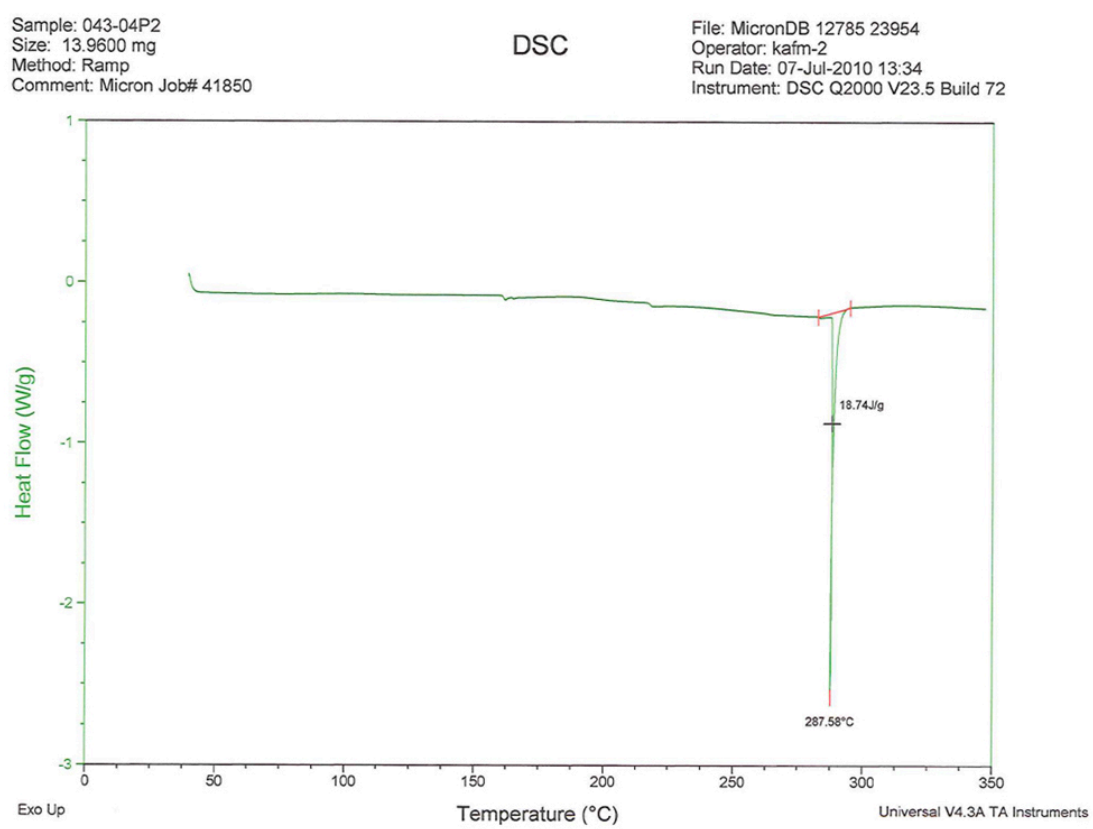

Figure 7. Differential scanning calorimetry (DSC) of LTS043 silver paste.

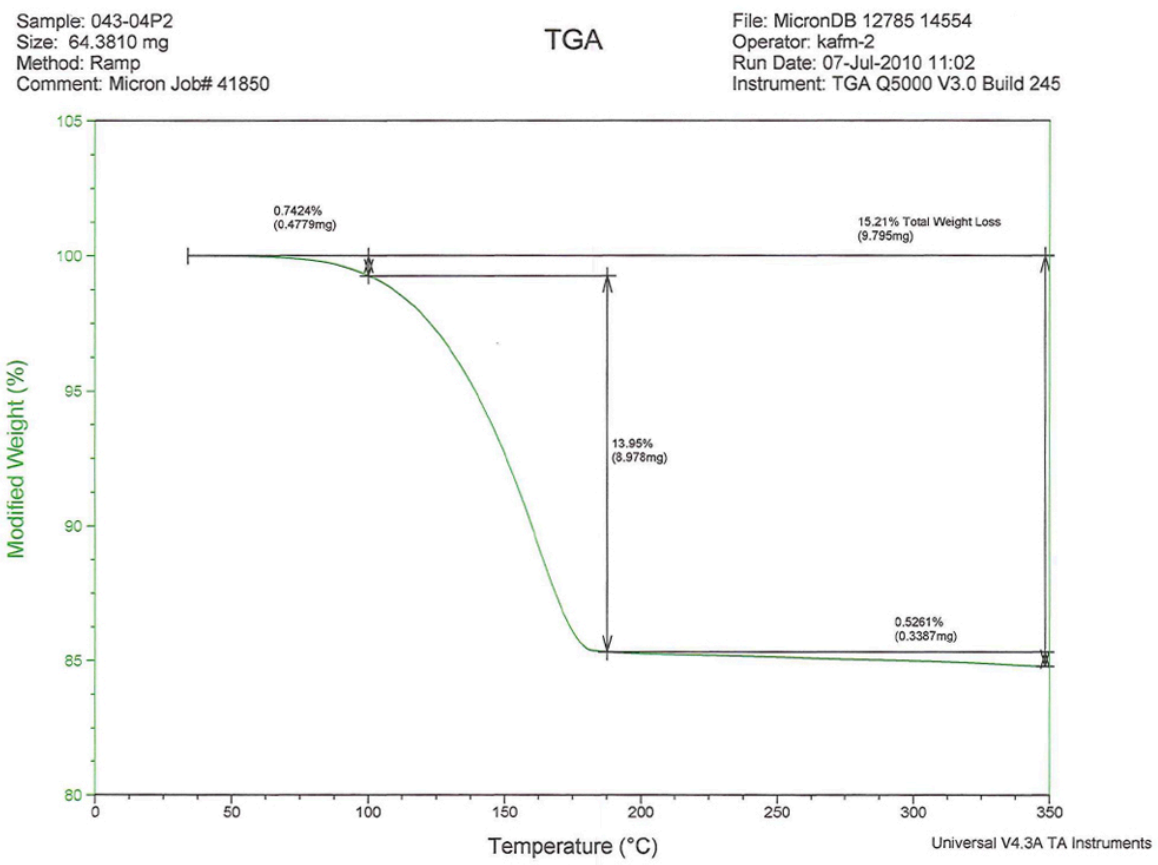

Figure 8. Thermogravimetric analysis (TGA) of LTS043 silver paste. 


\subsubsection{Processing of Coupons}

Bulk silver specimens were fabricated with pressure-assistance using a custom-made fixture utilizing a clamp-on, conductive-heater (Watlow, St. Louis, MO). Pastes were dried in ambient air, ground with a mortar and pestle, and sieved through a 100-mesh screen. The resulting dried silver powder is shown in Fig. 9. An amount of dried powder was weighed to produce a disk with thickness of $\sim 4-5 \mathrm{~mm}$. Its charging into the mold/heater is also shown in Fig. 9.

The assembled heating system is shown in Fig. 10. The location where the powder was compressed was centered vertically and subjected to an isothermal temperature during sintering. Two thermocouples for the clamp-on heater were located at the top and controlled heating and over-temperature protection, and an independent (third) thermocouple was positioned close to the work volume and actual temperature control was based on this thermocouple. The relatively massive (thick-walled) stainless steel tubular mold promoted an isothermal temperature during the sintering process. This system heated up and reached temperature equilibrium in approximately 5 minutes. Application of pressure commenced once that equilibrium was reached. Sintering temperature, stress, time-under stress, and apparent bulk density are listed in Table II.

Examples of produced disks are shown in Fig. 11. Specimens for property measurements were harvested out of these disks.
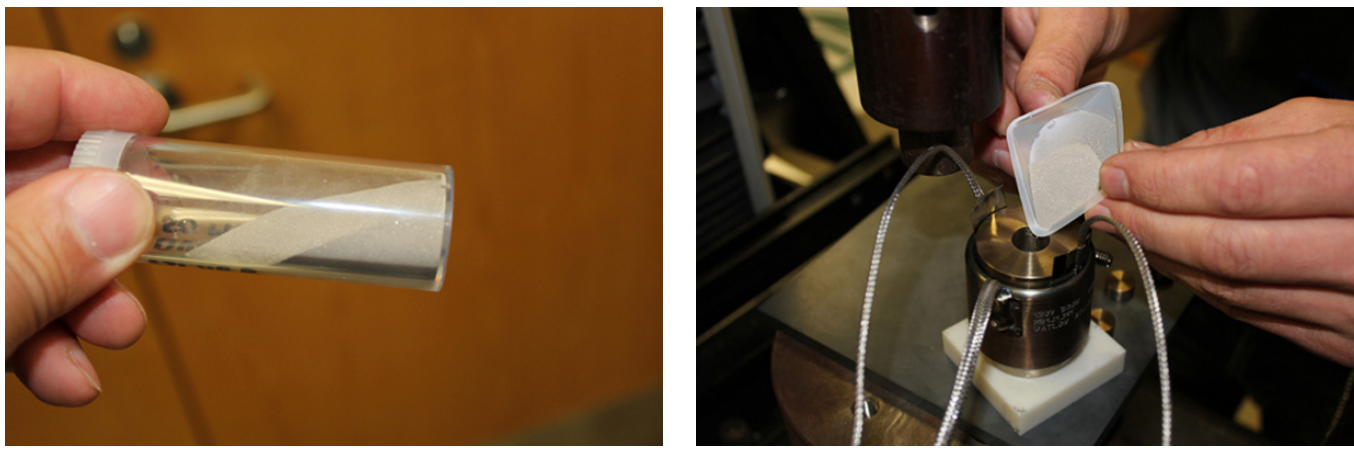

Figure 9. Dried silver powder (left) and it being poured into the mold (right). 

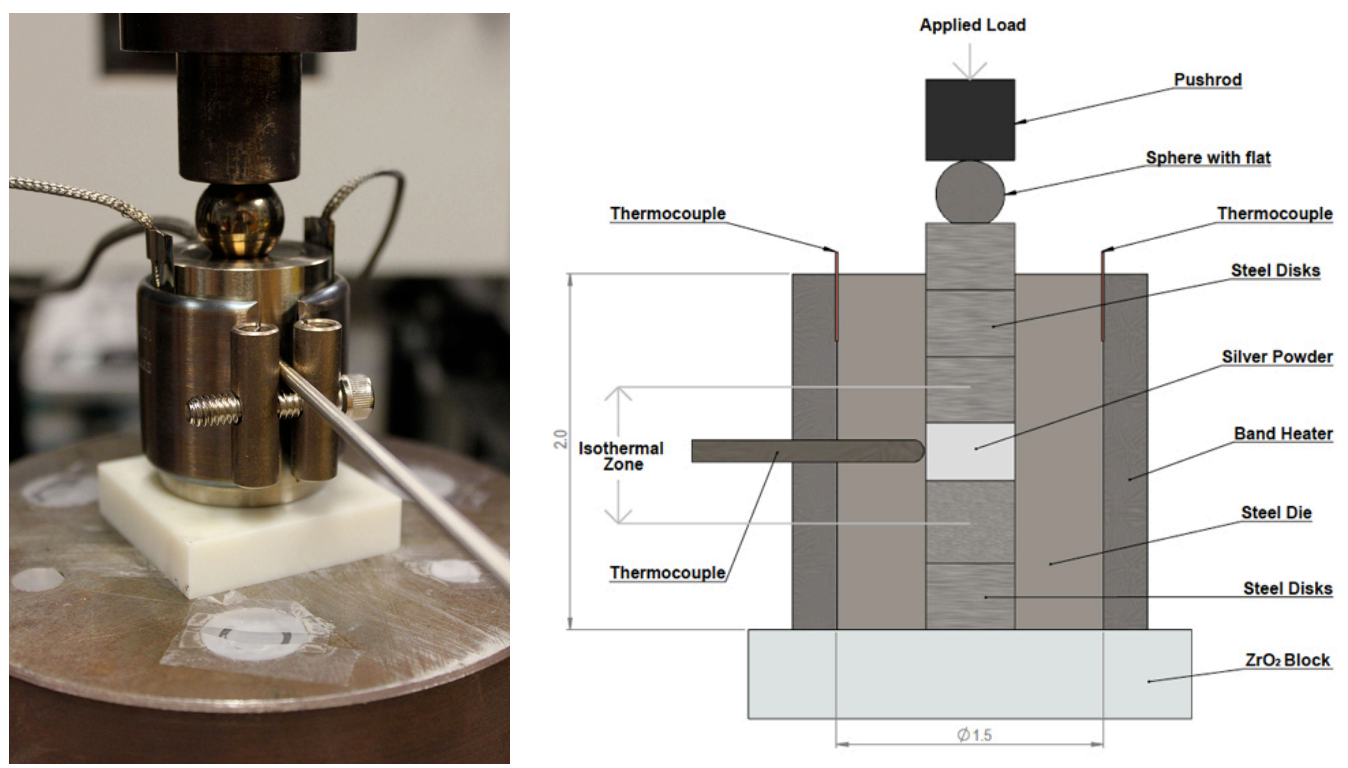

Figure 10. Assembled heating system (left) ready for pressure-assisted sintering and a schematic drawing of its structure (right).

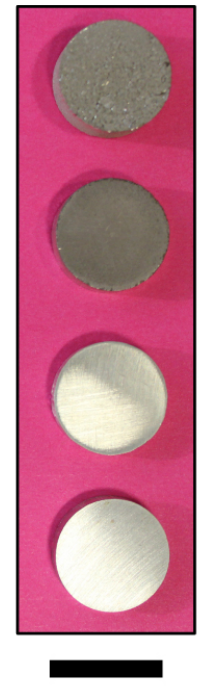

\section{Heraeus C1075S}

\section{DuPont LF131}

Heraeus LTS016

Heraeus LTS043

$12.7 \mathrm{~mm} \varnothing$

Figure 11. Examples of processed bulk silver coupons. 


\subsection{Property Measurements}

The intention of fabricating the bulk specimens was to enable the harvesting of sufficiently sized test coupons so electrical, thermal, and mechanical properties could be measured. Focused ion beam (FIB) milling (Hitachi FB-2000A, Hitachi, Ltd., Tokyo, Japan) and follow-on scanning electron microscopy (SEM) of the microstructures were performed on one test coupon from each of the four pastes listed in Table II.

\subsubsection{Electrical Resistivity and Conductivity}

Electrical resistivity was measured using an electric resistance measuring system (ULVAC ZEM-3, Methuen, MA). A small bar sample of $2 \times 2 \times 10 \mathrm{~mm}$ long was used. Measurements were made over a temperature range of $-50-200^{\circ} \mathrm{C}$. Two $\mathrm{R}$ type thermocouples were used as temperature and voltage probes. Current vs. voltage curves were obtained before each measurement to ensure good electrical contact. Electrical conductivity was calculated by inversing the electrical resistivity measurements.

\subsubsection{Thermal Conductivity}

A laser flash diffusivity measuring system (TA Instrument, New Castle, DE) was used for thermal diffusivity measurements. The TA/Anter X-platform has a two-sample holder and xenon flash lamp. Measurements were made over a temperature range of $-50 \mathrm{C}$ to $200^{\circ} \mathrm{C}$. The samples were $12.7 \mathrm{~mm}$ in diameter and 1-2 mm thick. The ASTM standard 1461 was followed in data collection and analysis. The thermal diffusivity is calculated using the Clark \& Taylor method. Thermal conductivity $(\kappa)$ of the material was calculated according to $\kappa=\alpha \cdot \rho \bullet \mathrm{Cp}$ where $\alpha$ is thermal diffusivity, $\rho$ is density, and $\mathrm{Cp}$ is heat capacity. Density was measured in all samples and $\mathrm{Cp}$ was assumed to be $240 \mathrm{~J} / \mathrm{kg} \cdot \mathrm{K}$ for all temperatures. 


\subsubsection{Coefficient of Thermal Expansion}

Coefficient of thermal expansion was measured using a dual-rod dilatometer (Dilatronic 1, Theta Industries, Port Washington, NY) using a sapphire standard in all tests. $2 \mathrm{x}$ $2 \times 10 \mathrm{~mm}$ specimens were used and measurements were taken from room temperature to $250^{\circ} \mathrm{C}$.

\subsubsection{Elastic Modulus and Poisson's Ratio}

Elastic modulus and Poisson's ratio were measured using a resonant ultrasound spectroscope (Magneflux, Albuquerque, NM). A $2 \times 2 \times 10 \mathrm{~mm}$ specimen was used and measurements were only made at room temperature.

\subsubsection{Yield Stress}

Yield stress was estimated using an electromechanical test frame (Model 5867, Instron, Canton, MA). Two prismatic bars with nominal dimensions of $3 \times 3 \times 4.5 \mathrm{~mm}$ were prepared. The $4.5 \mathrm{~mm}$ dimension was compressively loaded and the force associated with the onset of nonlinearity was identified using graphical analysis for each test. That force was divided by the $3 \mathrm{x}$ $3 \mathrm{~mm}$ cross-section to calculate the engineering yield stress. Only room temperature testing was performed. 


\section{RESULTS AND DISCUSSION}

3.1. Densities and Microstructures

The sintering conditions and produced densities are listed in Table II. A range of 62 to $97 \%$ of theoretical full density were produced.

Table II. Processing conditions and produced silver bulk densities.

\begin{tabular}{|c|c|c|c|}
\hline Silver Paste & $\begin{array}{c}\text { Sintering Conditions } \\
\mathrm{T}=\text { sintering temperature } \\
\mathrm{S} \text { uniaxial compressive stress } \\
\mathrm{t}=\text { time under stress }\end{array}$ & $\begin{array}{c}\text { Produced } \\
\text { Apparent } \\
\text { Bulk Density } \\
\left(\mathbf{g} / \mathbf{c m}^{\mathbf{3}}\right)\end{array}$ & $\begin{array}{c}\text { Produced } \\
\text { \% of } \\
\text { Full Density }\end{array}$ \\
\hline $\mathrm{C} \mathrm{1075} \mathrm{S}$ & $\mathrm{T}=250^{\circ} \mathrm{C}, \mathrm{S}=50 \mathrm{MPa}, \mathrm{t}=10 \mathrm{~min}$ & 6.46 & 62.1 \\
\hline LF131 & $\mathrm{T}=350^{\circ} \mathrm{C}, \mathrm{S}=50 \mathrm{MPa}, \mathrm{t}=10 \mathrm{~min}$ & 8.41 & 80.9 \\
\hline LTS 016 & $\mathrm{T}=350^{\circ} \mathrm{C}, \mathrm{S}=50 \mathrm{MPa}, \mathrm{t}=10 \mathrm{~min}$ & 8.42 & 81.0 \\
\hline LTS 043 & $\mathrm{T}=350^{\circ} \mathrm{C}, \mathrm{S}=50 \mathrm{MPa}, \mathrm{t}=25 \mathrm{~min}$ & 10.07 & 96.8 \\
\hline
\end{tabular}

$\dagger$ Theoretical density of silver $=10.4 \mathrm{~g} / \mathrm{cm}^{3}$.

Dual beam focused ion beam (FIB) milling (Hitachi FB-2000A, Tokyo, Japan) was performed on one test coupon from each of the four pastes listed in Table II. An illustration of the FIB milling layout is shown in Fig. 12 with the resulting images for the four porosity ranges shown in Fig. 13. The drawn boxes in Fig. 13 are regions where the porosity is representative of the bulk. The region between each box and the specimen's surface is not representative of the bulk porosity because their dense structure was a consequence of the (consolidating) surface grinding used to produce the overall test coupons. The amounts and changes of evident porosity among them is consistent with the measured apparent bulk density of each. 


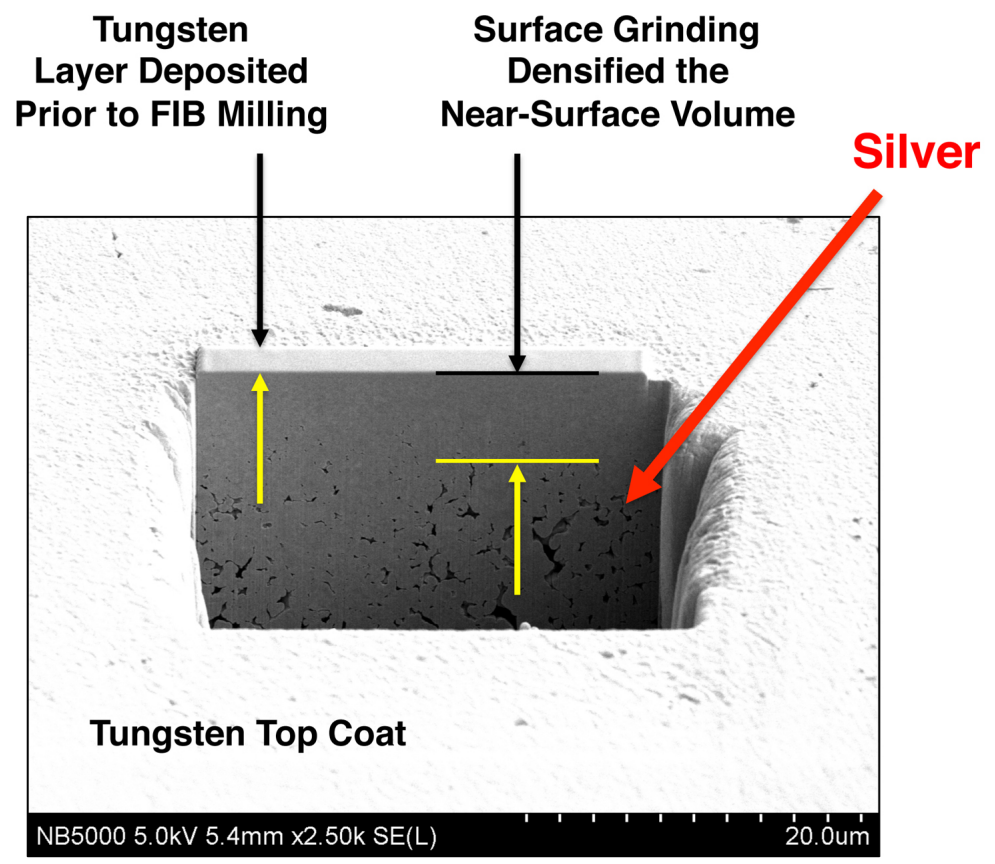

Figure 12. Example of a focused ion beam (FIB) milled trench.
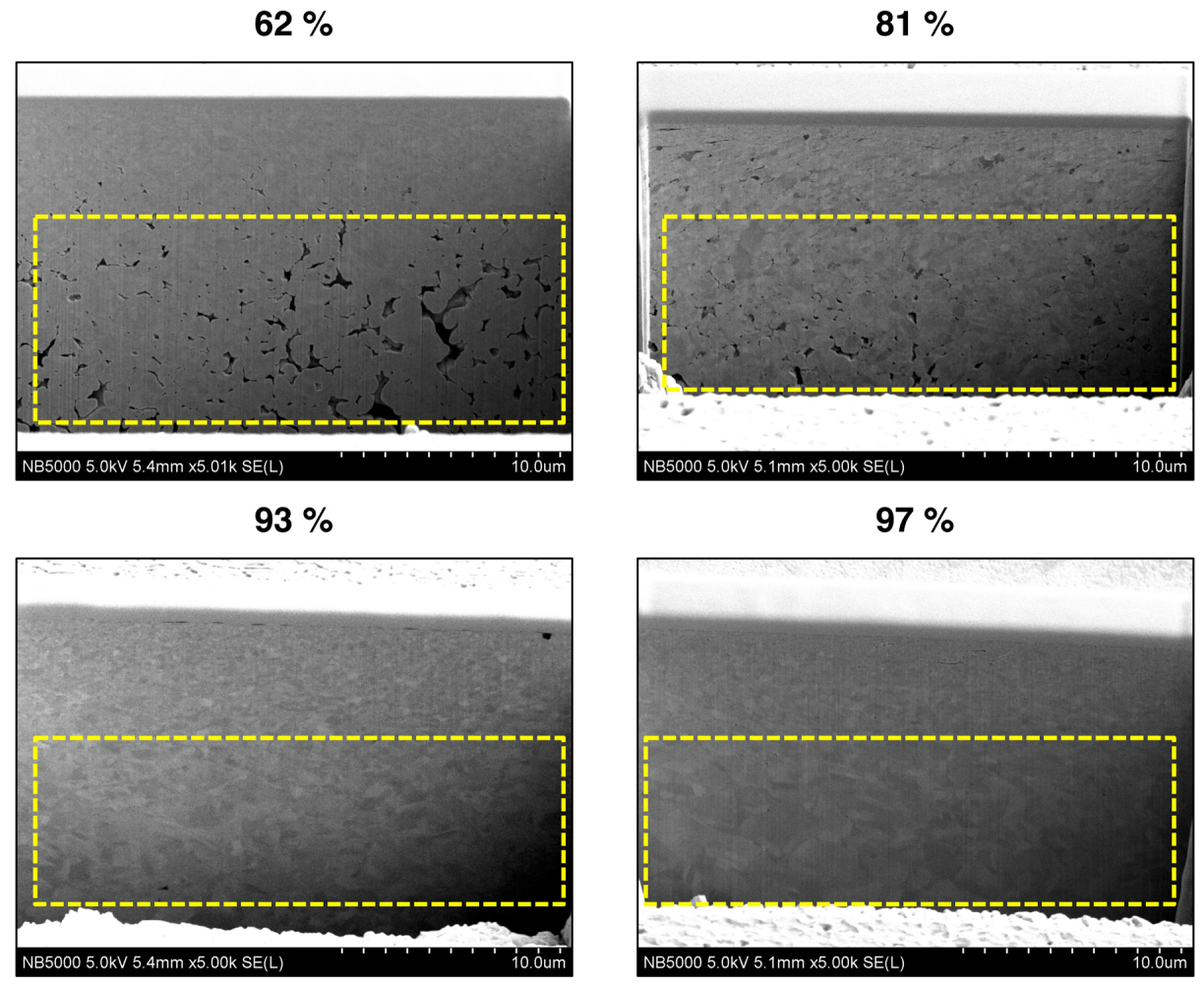

Figure 13. Structures formed by FIB milling as a function of porosity. 


\subsection{Property Measurements}

The resulting property measurements as a function of porosity follow.

\subsubsection{Electrical Resistivity and Conductivity}

Electrical resistivity as a function of porosity and temperature is shown in Fig. 14. Electrical resistivities quadrupled from when density decreased from $97 \%$ to $62 \%$ and increased with temperature. At room temperature electrical resistivity was $\sim 2 \mu \Omega \bullet \mathrm{cm}$ for $93-97 \%$ dense silver, $\sim 4 \mu \Omega \bullet \mathrm{cm}$ for $81 \%$ dense silver, and $\sim 8 \mu \Omega \bullet \mathrm{cm}$ for $62 \%$ dense silver.

Electrical conductivity as a function of porosity and temperature is shown in Fig. 15. Given reciprocity exists between electrical resistivity and conductivity, electrical conductivities decreased by approximately one-fourth when density decreased from $97 \%$ down to $62 \%$ and they decreased with temperature. At room temperature electrical conductivity was $40-50 \mathrm{MS} / \mathrm{m}$ for 93-97\% dense silver, $25 \mathrm{MS} / \mathrm{m}$ for $81 \%$ dense silver, and $~ 10 \mathrm{MS} / \mathrm{m}$ for $62 \%$ dense silver.

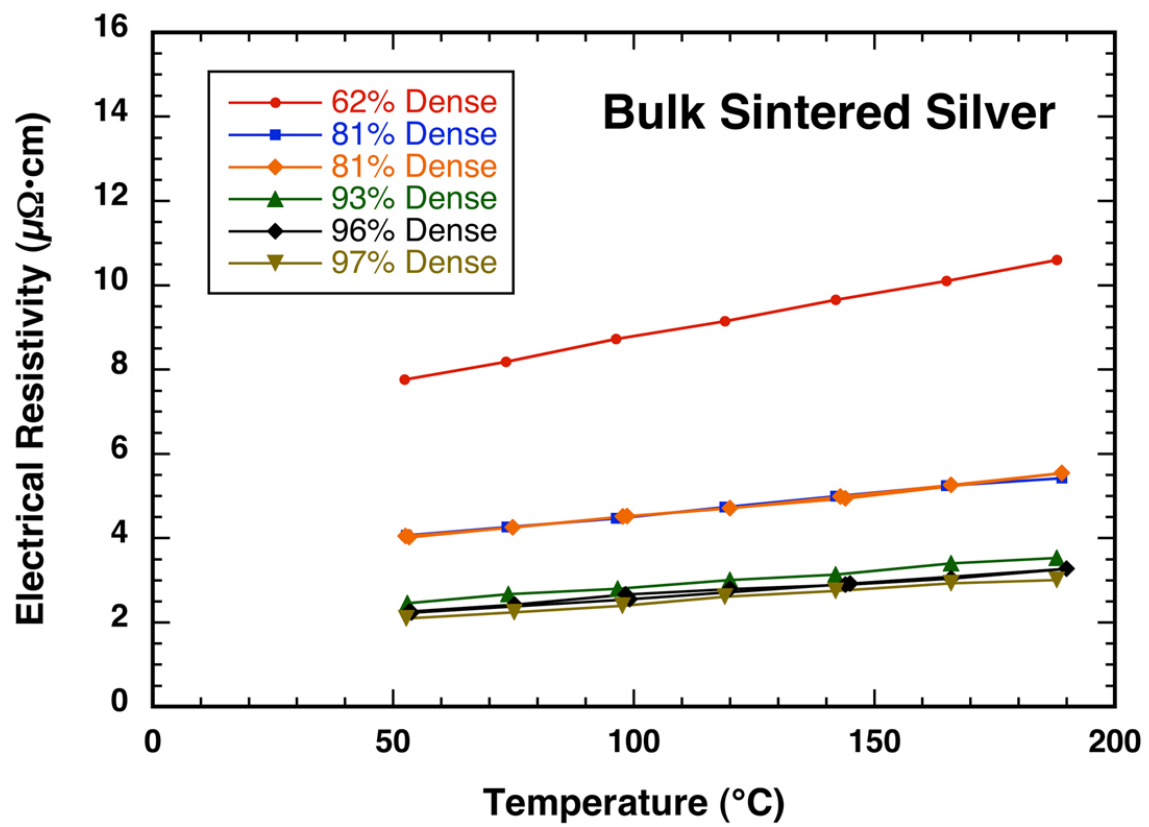

Figure 14. Electrical resistivity $(\rho)$ as a function of porosity and temperature. 


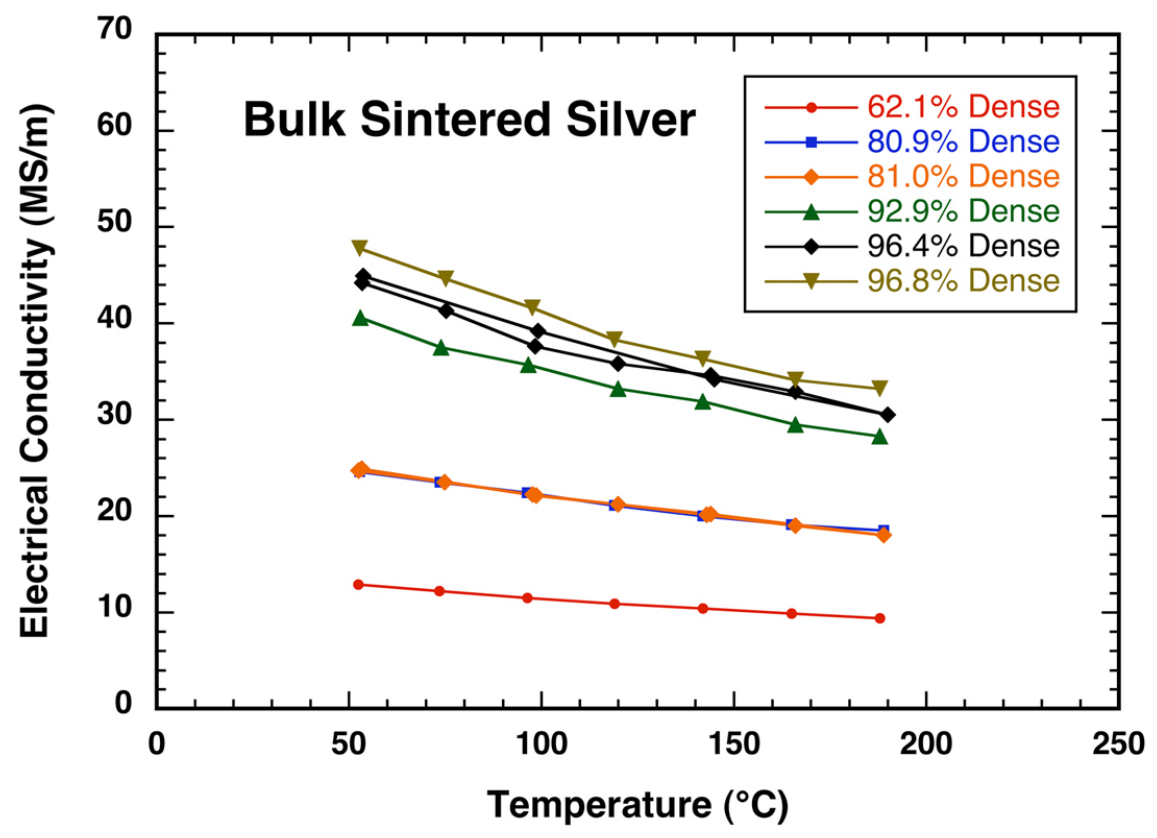

Figure 15. Electrical conductivity $(\sigma)$ as a function of porosity and temperature.

\subsubsection{Thermal Conductivity}

Thermal conductivity as a function of porosity and temperature is shown in Fig. 16. Thermal conductivity decreased by approximately $80 \%$ when the density decreased from $97 \%$ to $62 \%$. Thermal conductivities were temperature independent between -50 and $200^{\circ} \mathrm{C}$ for any given porosity level. At room temperature thermal conductivity was $\sim 375 \mathrm{~W} / \mathrm{mK}$ for $96 \%$ dense silver, $\sim 350 \mathrm{~W} / \mathrm{mK}$ for $93 \%$ dense silver, $\sim 175 \mathrm{~W} / \mathrm{mK}$ for $81 \%$ dense silver, and $\sim 75 \mathrm{~W} / \mathrm{mK}$ for $62 \%$ dense silver. 


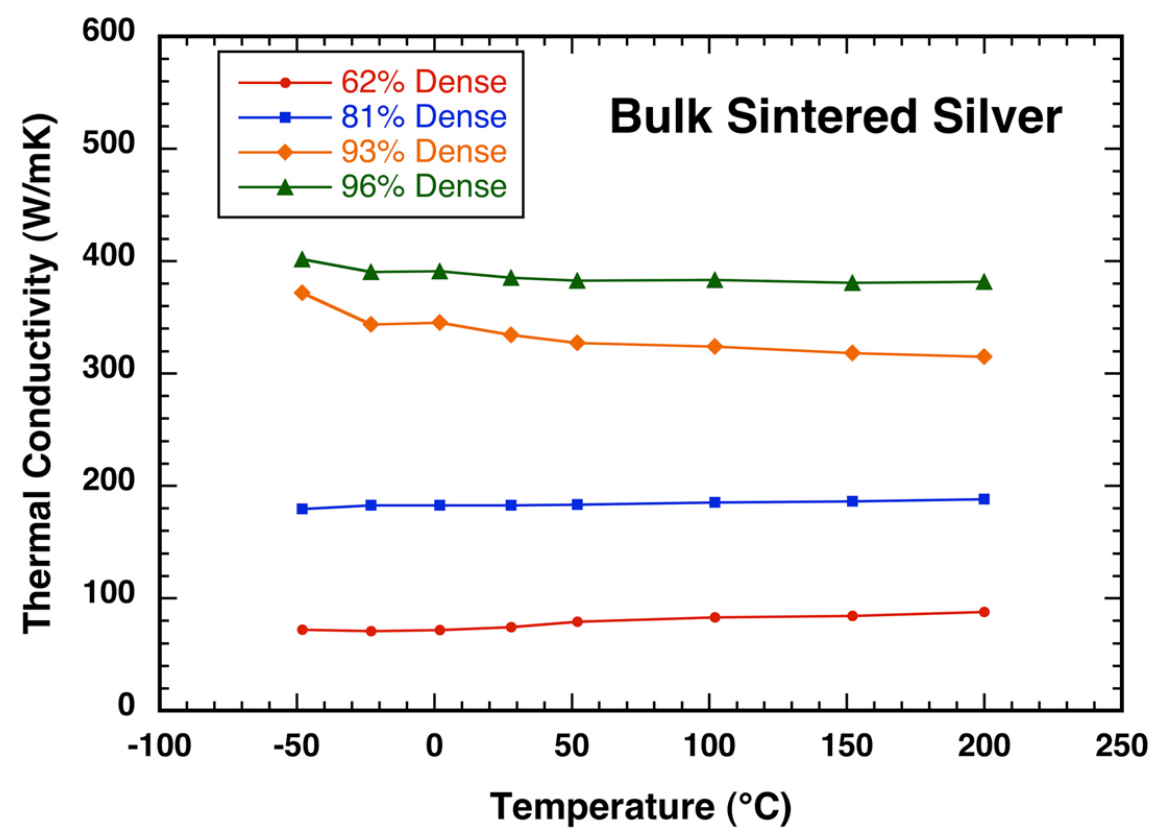

Figure 16. Thermal conductivity $(\kappa)$ as a function of porosity and temperature.

\subsubsection{Coefficient of Thermal Expansion}

Coefficient of thermal expansion as a function of porosity is shown in Fig. 17. The average CTE up to $250^{\circ} \mathrm{C}$ was independent of porosity and was approximately $20 \times 10^{-6} /{ }^{\circ} \mathrm{C}$. CTE was the only measured property in this study that was independent of porosity.

\subsubsection{Elastic Modulus and Poisson's Ratio}

Elastic modulus as a function of porosity is shown in Fig. 18. Elastic modulus decreased by approximately $80 \%$ when the density decreased from $97 \%$ to $62 \%$. Elastic modulus was $72 \mathrm{GPa}$ for $96-97 \%$ dense silver, $58 \mathrm{GPa}$ for $93 \%$ dense silver, $40 \mathrm{GPa}$ for $81 \%$ dense silver, and $14 \mathrm{GPa}$ for $62 \%$ dense silver.

Poisson's ratio as a function of porosity is shown in Fig. 19. Poisson's ratio decreased by approximately $45 \%$ when the density decreased from $97 \%$ to $62 \%$. Poisson's ratio was $\sim 0.37$ for $96-97 \%$ dense silver, $\sim 0.28$ for $81 \%$ dense silver and 0.20 for $62 \%$ dense silver. 


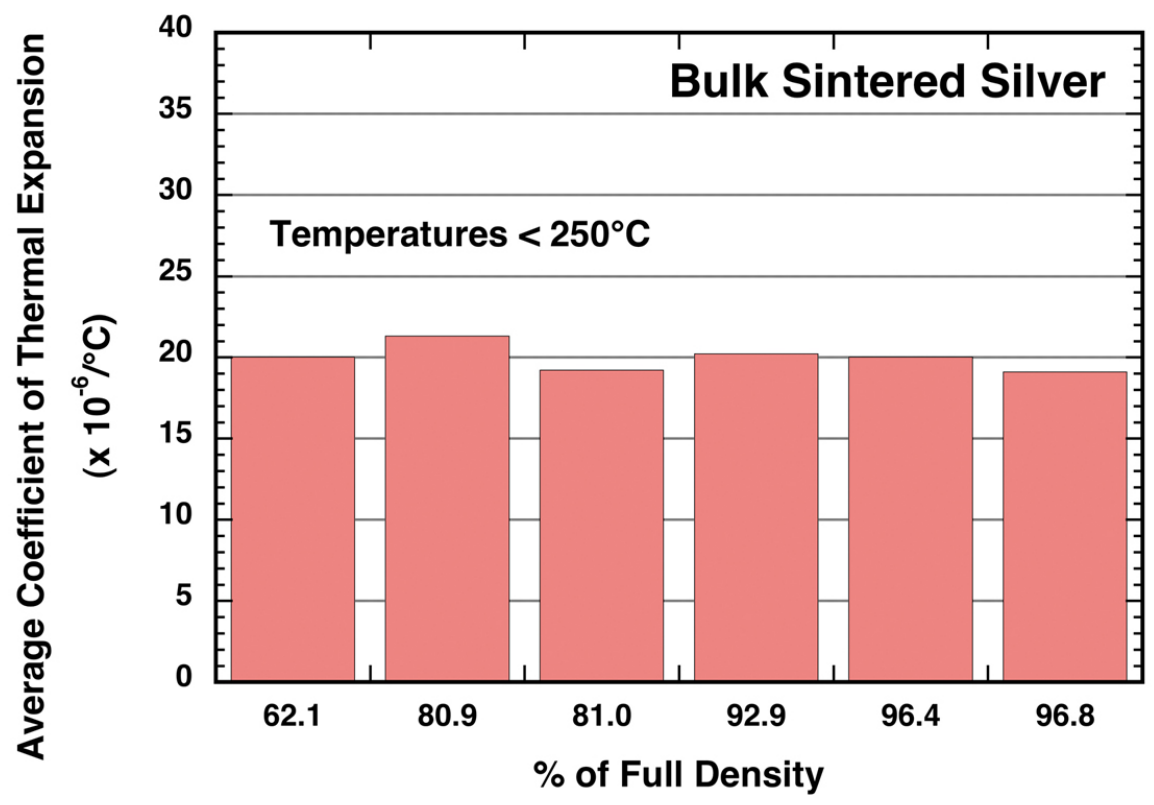

Figure 17. Coefficient of thermal expansion (CTE) as a function of porosity.

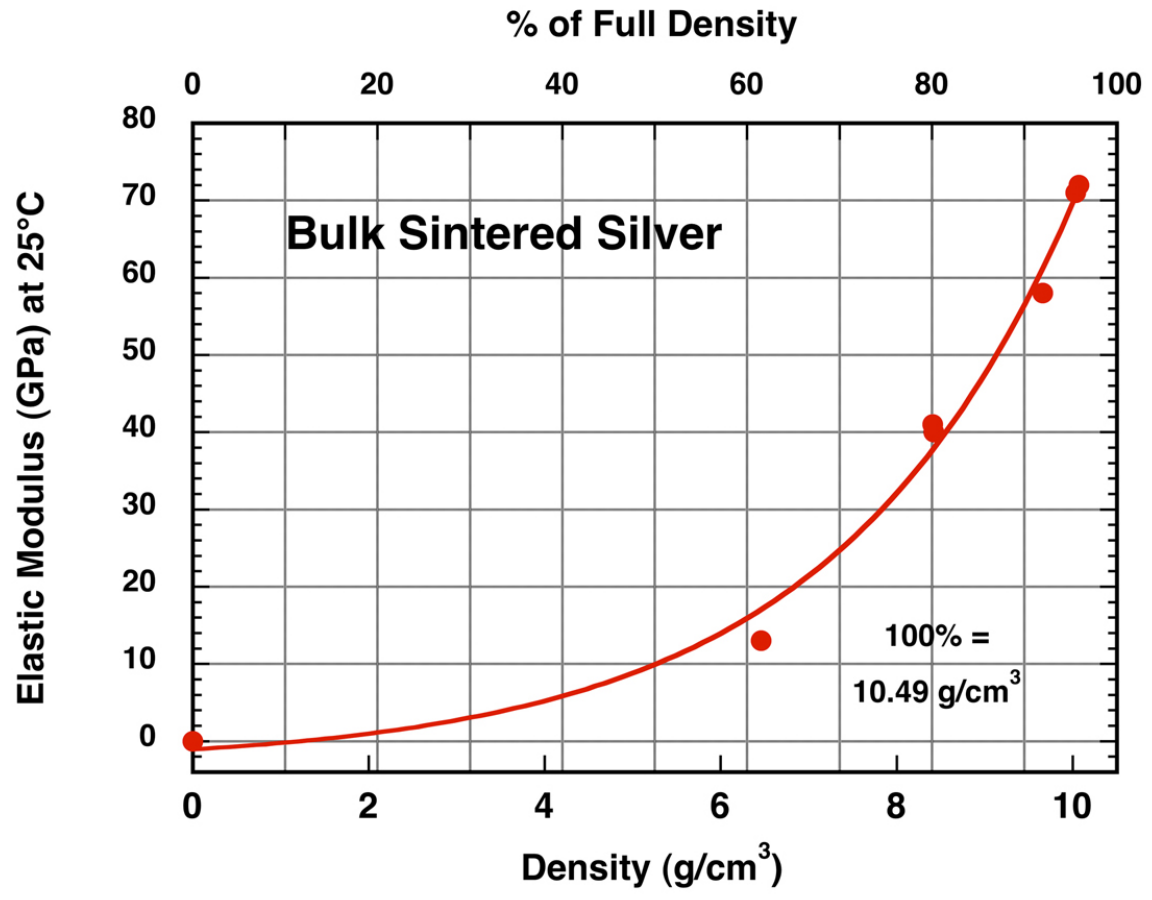

Figure 18. Elastic modulus (E) as a function of porosity at $25^{\circ} \mathrm{C}$. 


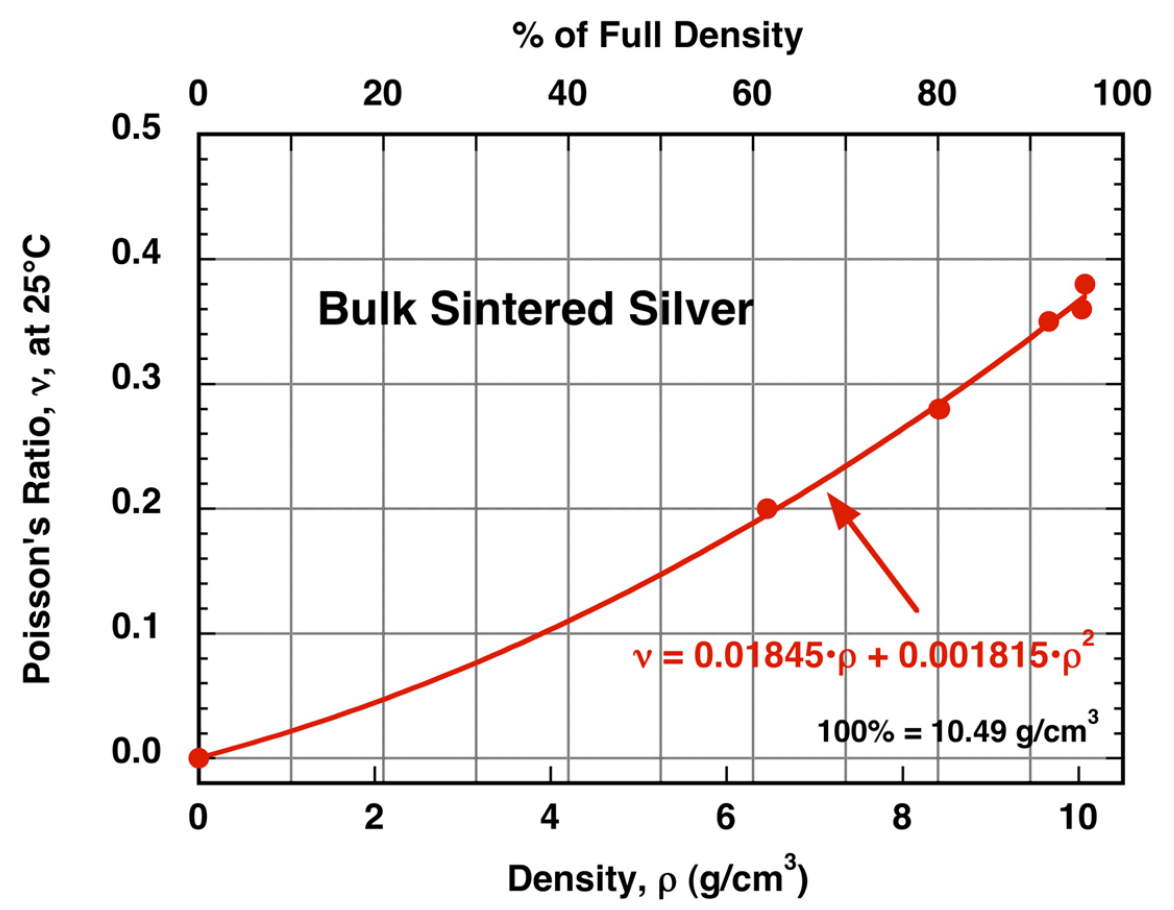

Figure 19. Poisson's ratio $(v)$ as a function of porosity at $25^{\circ} \mathrm{C}$.

\subsubsection{Yield Stress}

Yield stress as a function of porosity is shown in Fig. 20. Yield stress decreased by $\sim 70-80 \%$ when the density decreased from $97 \%$ to $62 \%$. The yield stress was greater than 60 MPa for densities $83 \%$ and higher and $\sim 20 \mathrm{MPa}$ for a density of $62 \%$.

Although the microstructure of the silver itself probably did not significantly affect the electrical, thermal, and elastic properties, it could have affected the yield stress response. A finer-grained structure usually deforms easier (i.e., has a lower hardness or yield stress) than a coarse-grained structure of the same material. It may then be suggested that micrometer-sized particle silver paste and nano-sized particle silver pastes produce equivalent electrical, thermal, and elastic properties but that nano-sized particle silver paste could have a lower yield stress than micrometer-sized particle silver paste (for the same porosity level). 


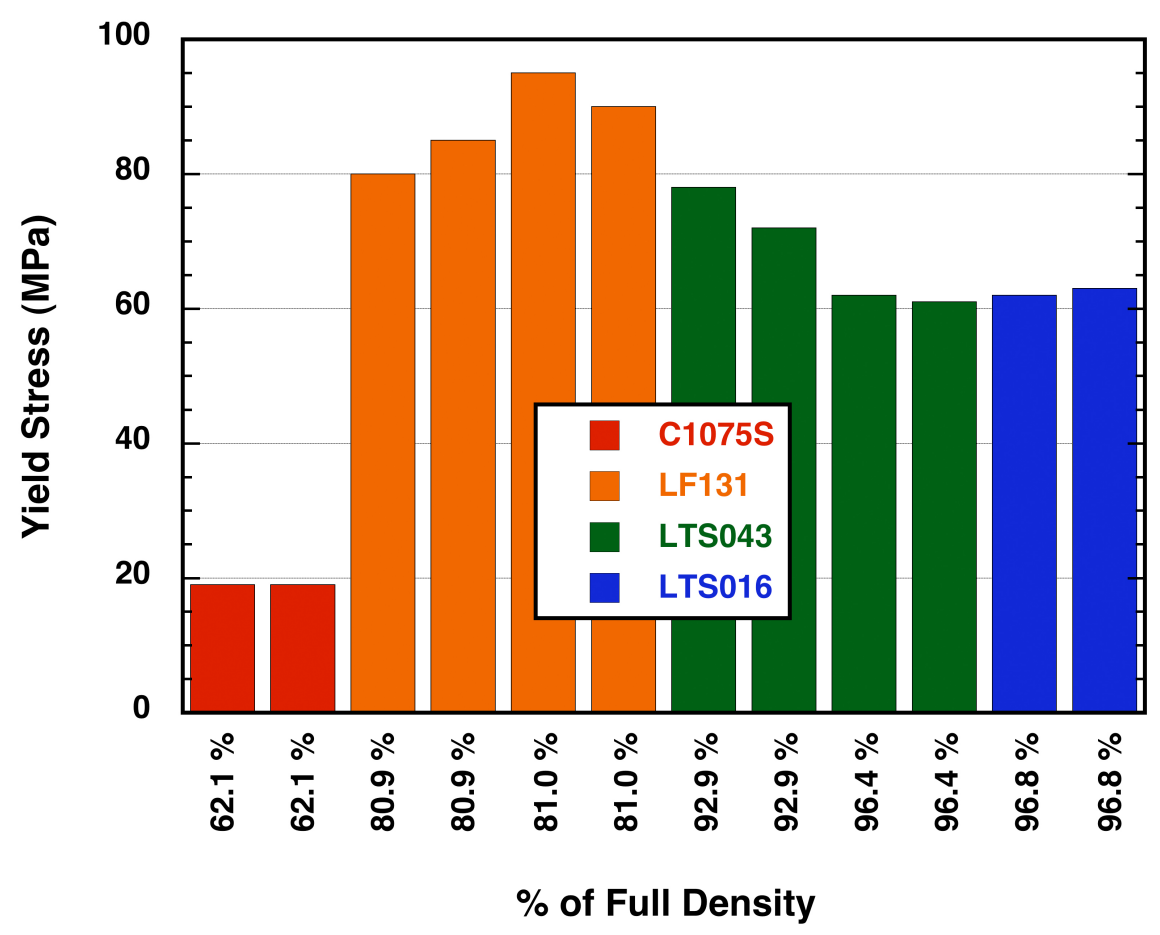

Figure 20. Yield stress $\left(\sigma_{\mathrm{Y}}\right)$ as a function of porosity at $25^{\circ} \mathrm{C}$.

\section{CONCLUSIONS}

- Electrical resistivity. Electrical resistivities quadrupled from when density decreased from $97 \%$ to $62 \%$ and increased with temperature. At room temperature electrical resistivity was $\sim 2 \mu \Omega \bullet \mathrm{cm}$ for $93-97 \%$ dense silver, $\sim 4 \mu \Omega \bullet \mathrm{cm}$ for $81 \%$ dense silver, and $\sim 8 \mu \Omega \bullet \mathrm{cm}$ for $62 \%$ dense silver.

- Electrical conductivity. Given reciprocity exists between electrical resistivity and conductivity, electrical conductivities decreased by approximately one-fourth when density decreased from $97 \%$ down to $62 \%$ and they decreased with temperature. At room temperature electrical conductivity was $40-50 \mathrm{MS} / \mathrm{m}$ for $93-97 \%$ dense silver, $\sim 25 \mathrm{MS} / \mathrm{m}$ for $81 \%$ dense silver, and $\sim 10 \mathrm{MS} / \mathrm{m}$ for $62 \%$ dense silver. 
- Thermal conductivity. Thermal conductivity decreased by approximately $80 \%$ when the density decreased from $97 \%$ to $62 \%$. Thermal conductivities were temperature independent between -50 and $200^{\circ} \mathrm{C}$ for any given porosity level. At room temperature thermal conductivity was $\sim 375 \mathrm{~W} / \mathrm{mK}$ for $96 \%$ dense silver, $\sim 350 \mathrm{~W} / \mathrm{mK}$ for $93 \%$ dense silver, $\sim 175 \mathrm{~W} / \mathrm{mK}$ for $81 \%$ dense silver, and $\sim 75 \mathrm{~W} / \mathrm{mK}$ for $62 \%$ dense silver.

- Coefficient of thermal expansion. The average CTE up to $250^{\circ} \mathrm{C}$ was independent of porosity and was approximately $20 \times 10^{-6} /{ }^{\circ} \mathrm{C}$.

- Elastic modulus. Elastic modulus decreased by approximately $80 \%$ when the density decreased from $97 \%$ to $62 \%$. Elastic modulus was $72 \mathrm{GPa}$ for $96-97 \%$ dense silver, 58 GPa for $93 \%$ dense silver, $40 \mathrm{GPa}$ for $81 \%$ dense silver, and $14 \mathrm{GPa}$ for $62 \%$ dense silver.

- Poisson's ratio. Poisson's ratio decreased by approximately $45 \%$ when the density decreased from $97 \%$ to $62 \%$. Poisson's ratio was $\sim 0.37$ for $96-97 \%$ dense silver, $\sim 0.28$ for $81 \%$ dense silver and 0.20 for $62 \%$ dense silver.

- Yield stress. Yield stress decreased by $\sim 70-80 \%$ when the density decreased from $97 \%$ to $62 \%$. The yield stress was greater than $60 \mathrm{MPa}$ for densities $83 \%$ and higher and $\sim 20 \mathrm{MPa}$ for a density of $62 \%$.

- Although the silver microstructure probably did not significantly affect the electrical, thermal, and elastic properties, it could have affected the yield stress response. A finergrained structure usually deforms easier (i.e., has a lower hardness or yield stress) than a coarse-grained structure of the same material. It may then be suggested that micrometersized particle silver paste and nano-sized particle silver pastes produce equivalent electrical, thermal, and elastic properties but that nano-sized particle silver paste could have a lower yield stress than micrometer-sized particle silver paste (for the same porosity level).

- The results show using appropriate electrical, thermal, and mechanical properties of sintered silver joints in the modeling power electronic devices will involve knowing what porosity exists in the sintered silver joint. 


\section{REFERENCES}

[1] Z. Zhang and G. -Q. Lu, "Pressure-Assisted Low-Temperature Sintering of Silver Paste as an Alternative Die-Attach Solution to Solder Reflow," IEEE Transactions on Electronics Packaging Manufacturing, [4] 25:279-283 (2002).

[2] J. G. Bai, Z. Z. Zhang, J. N. Calata, and G. -Q. Lu, "Low-Temperature Sintered Nanoscale Silver as a Novel Semiconductor Device-Metallized Substrate Interconnect Material," IEEE Transactions on Components and Packaging Technologies, [3] 29:589593 (2006).

[3] W. Schmitt, "Novel Silver Contact Paste Lead Free Solution for Die Attach," Paper 10.5, CIPS 2010, Nuremberg, Germany (2010).

[4] C. Göbl and J. Faltenbacher, "Low Temperature Sinter Technology Die Attachment for Power Electronic Applications," Paper 10.1, CIPS 2010, Nuremberg, Germany (2010).

[5] H. Zheng, J. Calata, K. Ngo, S. Luo, and G. -Q. Lu, "Low-Pressure ( $<5$ MPa) LowTemperature Joining of Large-Area Chips on Copper Using Nanosilver Paste," Paper 12.3, CIPS 2012, Nuremberg, Germany (2012).

[6] A. A. Wereszczak, D. J. Vuono, Z. Liang, and E. E. Fox, "Sintered Silver Joint Strength Dependence on Substrate Topography and Attachment Pad Geometry," Paper 12.4, CIPS 2012, Nuremberg, Germany (2012).

[7] J. -H. Zhao, Y. Du, M. Morgen, and P. S. Ho, "Simultaneous Measurement of Young's Modulus, Poisson's Ratio, and Coefficient of Thermal Expansion of Thin Films on Substrates," Journal of Applied Physics, [3] 87:1575-1577 (2000). 


\section{ACKNOWLEDGMENTS}

Research primarily sponsored by the Power Electronics and Electric Motors Program, DOE Office of Vehicle Technologies, under contract DE-AC05-00OR22725 with UT-Battelle, LLC. A small portion of this work $(<20 \%)$ was supported by the ARPA-E "Advanced Power Semiconductor and Packaging" project, Award DE-AR0000016, Lead Recipent - Delphi Automotive Systems, LLC, Sub-Recipients - International Rectifier and Oak Ridge National Laboratory.

The authors thank ORNL's R. Parten, S. Waters, D. Coffey, E. Fox, T. Morriseey, and L. Marlino, General Motors's Y. Zheng, V. Grosu, and G. Smith, Delphi's G. Eesley, and Heraeus's W. Schmitt and T. Krebs for their provided assistances and encouragement, and ORNL's P. Ning and R. Wiles for their review of this report and helpful comments. 


\section{APPENDIX: Silver Paste Manufacturer Technical Literature}

\section{Heraeus}

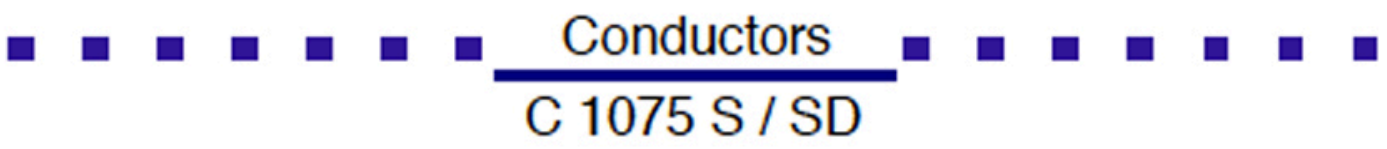

\section{Silver Conductor Paste}

\section{Deecription:}

C 1075 S / SD are low coet, oxide-bond pure Ag conductor materials. They offer cost savings over standard Ag / Pd

formulations, while maintaining the advantages of leach resistance and aged adhesion. C 1075 S is for use on alumina, and C 1075 SD is for use in mutlayer applications, in combinason with the didectric IP 9117 sories.

Resulting films are dense and unilorm. These pastes offer the best characteristics of a fritless matorial, bogether with the advantages of a mixed-bond system.

- Excellent solderability and lesch reeistance

- Solderable on alumina and dielectric IP 9117 series

- Compatble with HERAEUS reeistors

- Good intial and sgod sdhesion, even aftor muttiple firings

- Inner layer for multilayer applications

- Oustanding conductivity

\section{Processing:}

1. Spatulate well prior to processing. When stored in a fridge: The paste should have acquired room temperature belore being opened, to avoid condensation.

2. Print trough a $200-325$ mesh stainless stoel screen. Total thickness: $50-110 \mu \mathrm{m}$

3. Level at room ternperasure for 5-10 minutes.

4. Dry at $150^{\circ} \mathrm{C}$ for $10-20$ minuses.

5. Fire at $850 \mathrm{C}$ (peak) for 10 minutes, and with a total firing cycle time of c. $30-60$ minutes.

Thinner:

HVS 100

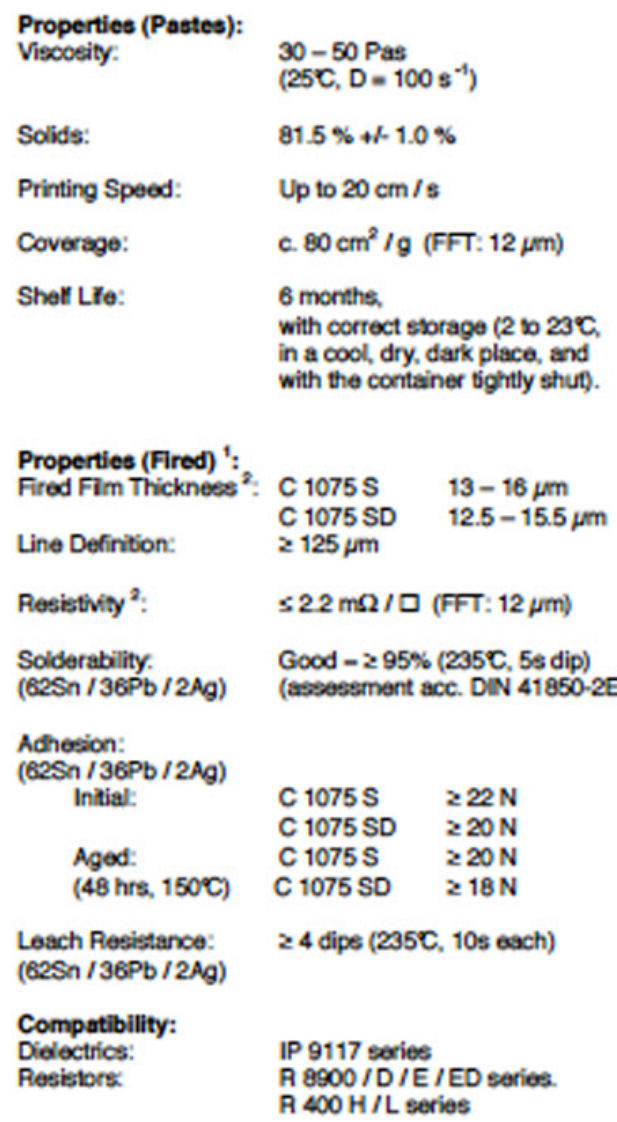

Shet Lfe:

6 months. with correct ssorage $(2 \times 23)^{\circ}$, in a cool, dry, dark place, and with the container tignttly shut?.

Properties (Fired) ':

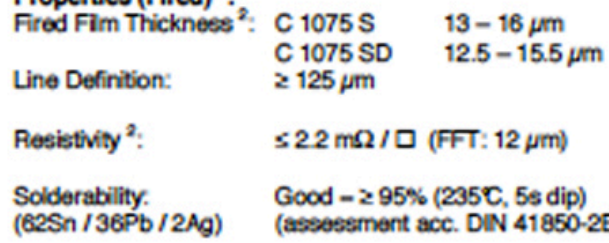

Adhesion: (62Sn / $36 \mathrm{~Pb} / 2 \mathrm{Ag})$ Intial:

C $1075 \mathrm{~S} \quad 222 \mathrm{~N}$ C 1075 SD $\geq 20 \mathrm{~N}$ C $1075 \mathrm{~S} \quad 220 \mathrm{~N}$

Aged: (48 hrs, $150^{\circ}$ )

C $1075 \mathrm{SD} \geq 18 \mathrm{~N}$

Leach Resistance: (62SA / $36 \mathrm{~Pb} / 2 \mathrm{Ag})$

Compatibility:

Dielectrics:

24 dipe (235C, 10 s asch)

Resistors:

IP 9117 sories A $8900 / D / E / E D$ series. R $400 \mathrm{H} / \mathrm{L}$ series

1 Typical proporty beod on laboratory trat mothoda. For optimum resuls all matorials should bo firod in a protibd tumsce suppliod with dribd, mydrocarbon froo and other contaminant, froe air (PP. 1).

2 Moasurod athor printing whth a 200 meeh stool scroon; scroon thickness and omulaion thicknose combinod was c. $100 \mathrm{\mu m}$, and the reautant printed track wae $500 \mathrm{\mu m}$ wido. 


\section{Heraeus}

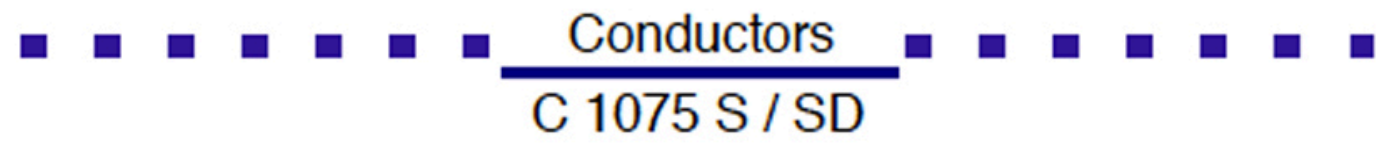

\section{Silver Conductor Paste}

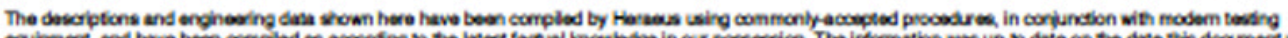

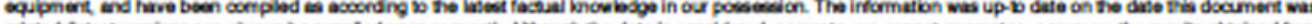

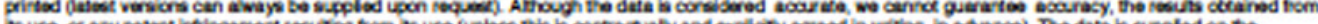

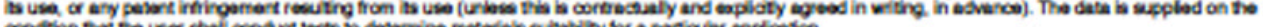

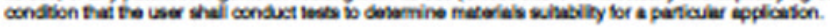

\section{Europe [TH]}

W.C. Heraeus GmbH

Thick Fim Materials Division

Heraeusstr. 12 - 14

63450 Hanau

Germany

Tel: $\$ 49$ (6181) $35-5486$

E-Mail: th-info@haraeus.com

Internet: www.heraeus-th.com

$110406 / \mathrm{FL}$
North America

Heraeus Incorporated

Thick Fim Materials Division

24 Union Hill Road

W. Conshohocken, PA 19428

USA

Tel: +1 (610) $825-6050$

E-Mal: techearvice.hod $\$$ heraeus.com Internet: www.thickfilm.net

\section{Asia [TH]}

Heraeus Materials Technology Shanghai Ltd.

No. 1 Guang Zhong Road

Zhuanquiao Town, Minhang District

201108 Shanghai

People's Republic of China

Tel: 486 (21) 33575473

E-Mal: th.hmsaheraeus com Internet: www.heraous-th.com 


\section{DuPont LF131}

\section{SILVER CONDUCTOR}

Technical Data Sheet

\section{Product Description}

DuPont LF131 silver conductor composition is intended to be applied to ceramic substrates by screen printing and firing in a conveyor furnace in an air (oxidizing) atmosphere. It has been developed to form interconnection tracks and pads for component and lead attachment, in hybrid microcircuits and networks.

\section{Product Benefits}

- Excellent fine line resolution

- Lead, cadmium and nickel free*

- Excellent solderability with $\mathrm{SnPb}, \mathrm{SnAg}$ and SAC solders.

- Excellent green-strength

- Compatible, sequentially or co-fired, with DuPont LF151 dielectric as a crossover or inner layer conductor

"Cadmlum, lead and nickel Tree" as used nerein means that these are not intentionally added to the referenced product. Trace amounts however may be present.

\section{Processing Conditions}

Printing

$200-325$ mesh stainless steel, $0.3-0.5$ mil emulsion. Print speeds up to $20 \mathrm{~cm} / \mathrm{s}$.

\section{Drying}

Allow prints to level for 5 - 10 minutes at room temperature, then dry for $10-15$ minutes at $150^{\circ} \mathrm{C}$.

Firing

$850^{\circ} \mathrm{C}$ peak held for 10 minutes on 30 minutes cycle in air (oxidizing) atmosphere.
Typical Composition Properties

\begin{tabular}{|l|c|}
\hline \multicolumn{1}{|c|}{ Test } & Properties \\
\hline Viscosity (Pa.s) \\
Brookneld HBT. UC8SP $\left.\$ 10 \mathrm{~mm}, 25^{\circ} \mathrm{C}\right]$ & $83-145$ \\
\hline Thinner & 4553 \\
\hline
\end{tabular}

Typical Fired Properties

\begin{tabular}{|c|c|}
\hline Shrinkage (dried to fired) [\%] & $56-62$ \\
\hline $\begin{array}{l}\text { Mean fired thickness: } \\
\text { (using } 200 \text { mesh) }[\mathrm{rm}]\end{array}$ & $13-19$, typical $16 \mu \mathrm{m}$ \\
\hline Coverage @ 16um fired $\left(\mathrm{cm}^{2} / \mathrm{g}\right)$ & $67-72$ \\
\hline 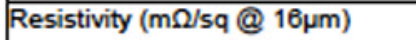 & $<2.0$ \\
\hline $\begin{array}{l}\text { Soldered } \\
\text { Adhesion' } \\
\text { Initial }(\mathrm{N}) \\
\text { Aged }\left(1000 \mathrm{hrs} @ 150^{\circ} \mathrm{C}\right)[\mathrm{N}]\end{array}$ & $\begin{array}{l}>20 \\
\geq 18\end{array}$ \\
\hline 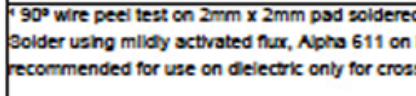 & 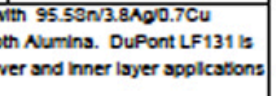 \\
\hline
\end{tabular}


Typical 30-minutes fire profile

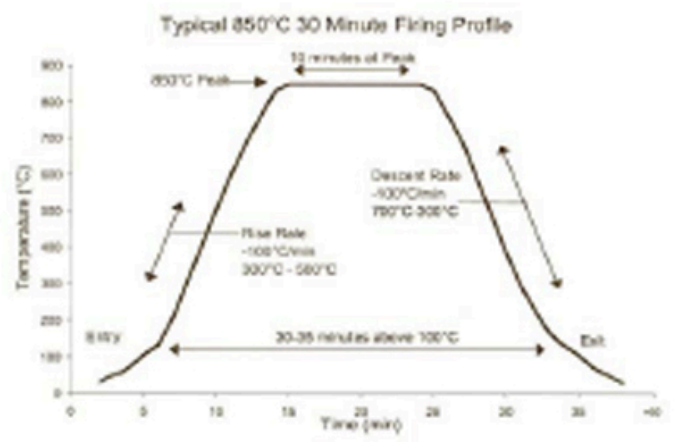

Storage and Shelf Life

Containers should be stored, tightly sealed, in a clean, stable environment at room temperature $\left(25^{\circ} \mathrm{C}\right)$. Shelf life of material in unopened containers is six months from date of shipment. Some settling of solids may occur and compositions should be thoroughly mixed prior to use.

Safety and Handling

For Safety and Handling information pertaining to this product. read the Material Safety Data Sheet (MSDS).

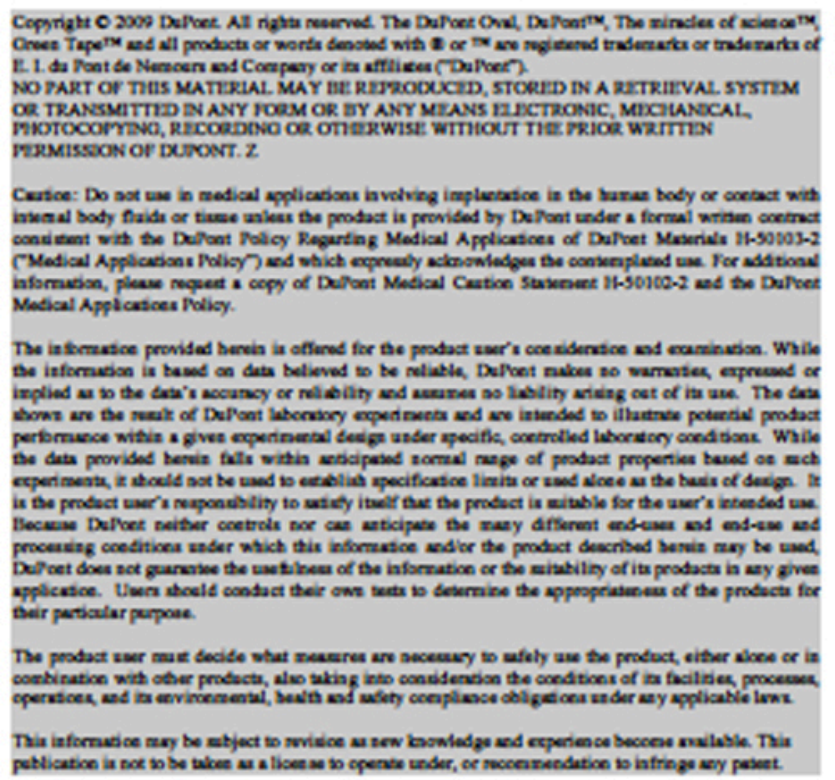

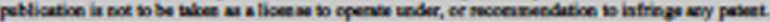

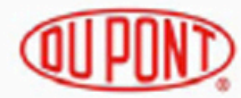

The miracles of science

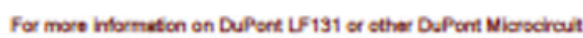
Materise product, please combet your loced rapensentativ:

Bention

Duont Marodiout Materis

14 T.W. Rlexender Otive

Ressecth Triendo Pek NC 27700

Tel.: 800-254-3982

\section{Exares}

Du Pont (U.K) Liminad

Colatietour Line

Bhatal BS16 10D

U.K.

Ta: 4-117-601-3101

Aats

D.Pont Kacuriw Keisha

Benno Pek Tower, 11-1

Negractio 2 ehome

Ciboderk, Tolyo t60-61:

Jeen

Tel: : 81-3-5621-8650

D.Pont Twamen Las

45, Haing-Pont Rewd,

Twoyean, Twawe 390

Tel: $888-3-377-3818$

Dufort Caine Holding Ca. Lted

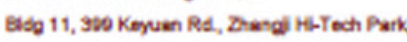

Rudong New Dtwitet Shanghel 201203 , China

To.: 88-21-6586-6368 ant2202

Dupont Korta inc

3-5e Flocr, Raia tower 4728 ,

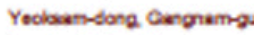

Secul 195-712, Korta

Ta.: 62-10-6585-5360

E. L. DuPont inds Pavese Limited

7th Flock, Tower C, DUF Oyer Creess.

Sectar-25A OLF CIy, Phesellt

Curpeon 122002 Heryeras inda.

Te.: 07-124-4001818

Du Pont Cempeny (Singepore) fore Lid

1 Hebourfroet Pres, 11 1-01

Herbeurfrong Tewer One.

Singepore cosess

Ta.: 65-6586-3022

http:Nmem dupoetcoen 


\section{Heraeus}

Technical Datasheet

\section{Silver contact paste}

\section{LTS 016 \& 043 Series}

\section{Silver Paste For Low Temperature Sinter}

Technology (LTST)

\section{Description}

The sllver pastes were developed for the Low Temperature Sinter Technology (LTST)

The pastes are used for power electronic applications for operating temperature above $150^{\circ} \mathrm{C}$ and replaced lead free and high lead containing soider aloys. They also increase the rellabllty of standard devices. At the moment 2 versions avallable. The LTS 016-01P1 for printed layer thicknesses untl $50 \mu \mathrm{m}$ and the LTS 043-04P2 for layers above 50-100 $\mu \mathrm{m}$.

\section{Characteristics}

- Excellent printing

- Screen and stencl pr

- Long process time
- Long green strength

- Some processing parameters between 20 and $32^{\circ} \mathrm{C}$

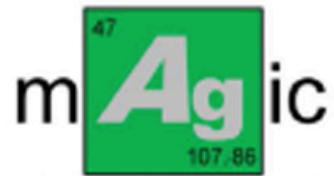

Microbond Silver Interconnect

\section{Typical Properties Of Pastes Bofore Sintering}

\begin{tabular}{l|ll}
\hline Silver content & $83 \pm 2 \%$ & \\
\hline Particles & $<20 \mu \mathrm{m}$ & \\
\hline VIscosity" & $5-15$ Pas & LTS 016-07P1 \\
& $15-35$ Pas & LTS 043-04P2 \\
\hline Procesain? ime & $4-6 \mathrm{~h}$ & \\
\hline UIme between print and place & $4-6 \mathrm{~h}$ &
\end{tabular}

1) At shear rate $\mathrm{D}-30 \mathrm{z}^{\circ}$. Piste cone aystem wh cone $2^{\circ}$, Terperature $23^{*} \mathrm{C}$.

2) Tme which tre pastes con proceed on the printer

3) Mox time betueen pritting and plachng the components (depends on the environment)

Dependency of viscosity to temperature

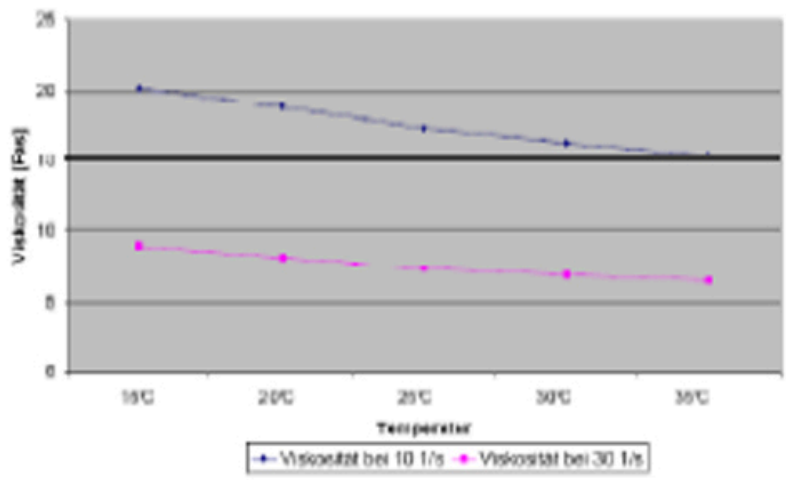

05.05.2010 WS

$1 / 5$

W, C., Heraęus 


\section{Heraeus}

DSC Analysis

Atmosphere alr, Heat rate $10 \mathrm{~K} / \mathrm{m} / \mathrm{n}$

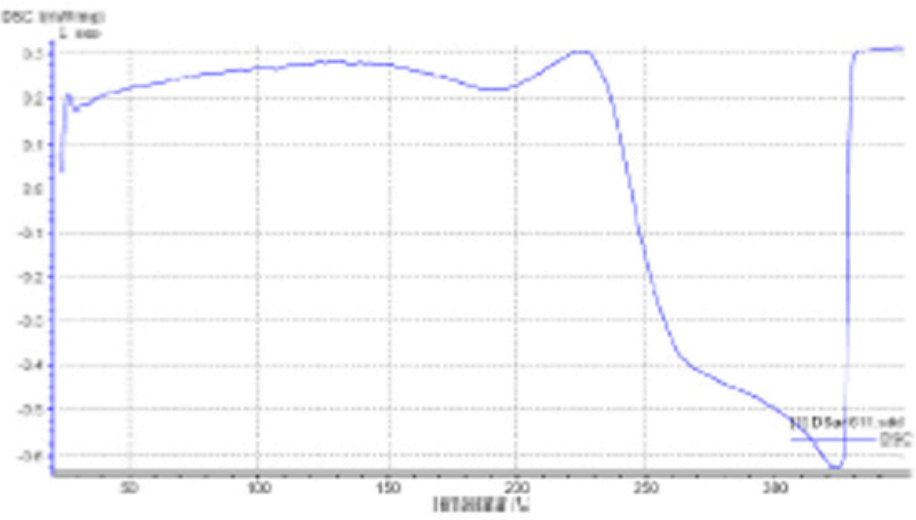

The sllver contact pastes sintered between 220 and $250^{\circ} \mathrm{C}$.

Recommended process temperature $\geq 250^{\circ} \mathrm{C}$

3. Recommended process parameters

Print

- The jars should reached the room temperature before opened to prevent condensation.

- Before using the paste should be homogenized.

- Pastes can print with screen and stencil.

- Typical parameters for screen printing: Nesh $200-325$ mesh; $45^{\circ}-60^{\circ}$ Pu-squeeze

- Typical parameters for stencll printing: $50 \mu \mathrm{m}$ stencll thickness (LTS 016-07P1)

50-100 jm stencil thickness (LTS 043-04P2)

$50 \mathrm{~mm} / \mathrm{s}$ print speed

0,1-0,3 N/mm print pressure (200mm force 20-60N)

5-10 mm/s separation speed

- Possible print time at $20-32^{\circ} \mathrm{C}$ is $4-6$ hours.

- The pastes keeps sticky between 2 and 6 hours depending on the environment

- The paste wills typical dried before sintering. The graph shows the printing behavior of a $10 \times 15 \times 0,05 \mathrm{~mm}$ printed layer at different temperature. 


\section{Heraeus}

Drying of an unseald paste layer

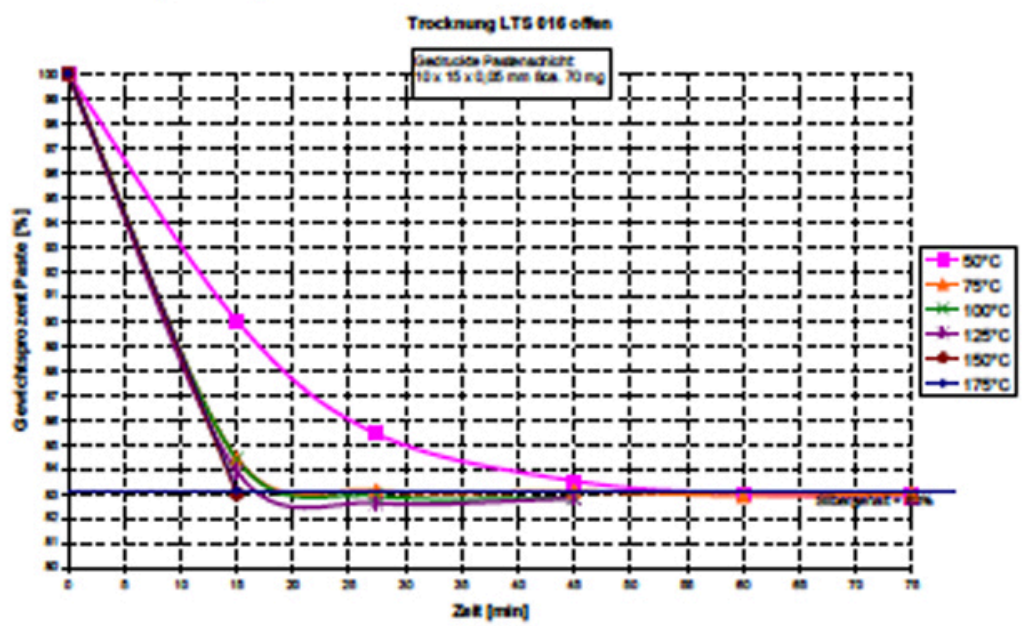

Drying of a sealed paste layer

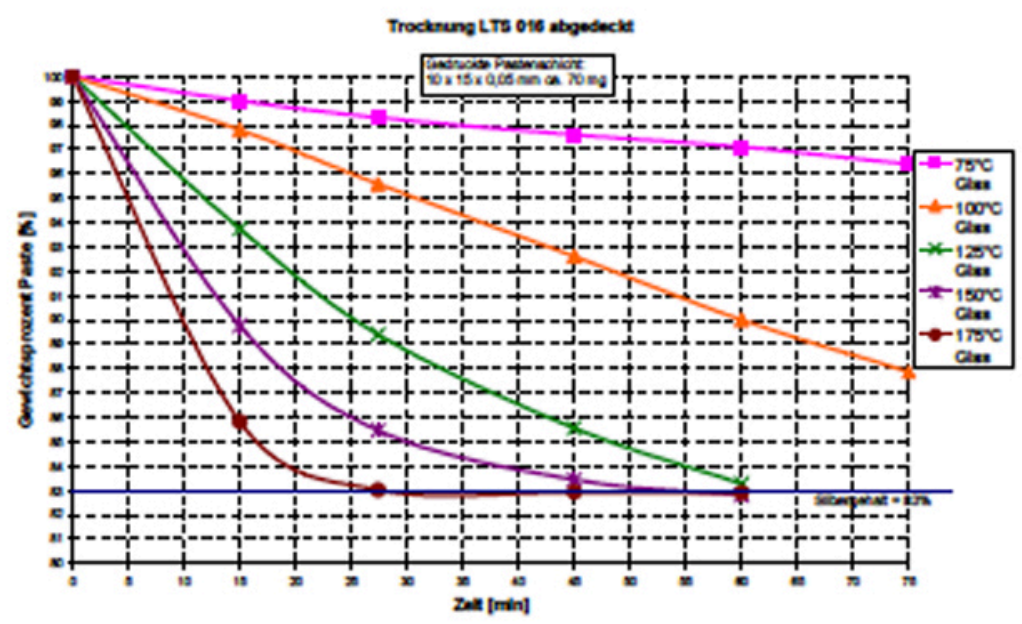




\section{Sintering}

- Gold- and Silver surfaces are recommended

- The parameters are denned by the customer

- Literature (German):

- Die Nledertemperatur-Veroindungstechnik der Lelstungselektronik; Mertens Christian, VDI Verlag 2004; ISBN 3-18-336521-9

- Aufoaukonzepte for dle Lelstungselektronlk mit der Nledertemperatur-Verbindungstechnlk; Rudzw Jacek; VDI Verlag 2006; ISBN 3-18337621-0

\section{Sintering teat}

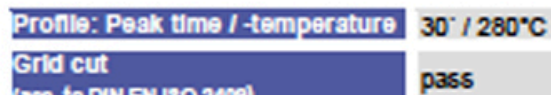

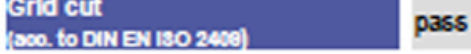

Grid cut LTS 016-01P1 on DCB-Substrate (surface gold)
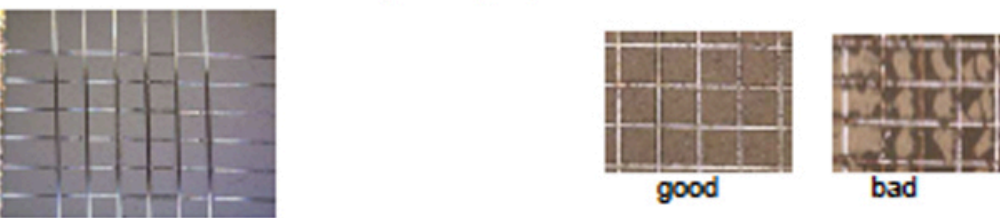

bad

Porosity (without preseure) $\quad 60-70 \%$

For low porosity and high conductivity a high pressure while sintering is necessary.

See reference curve (source VDI Veriag: Autor Mertens)

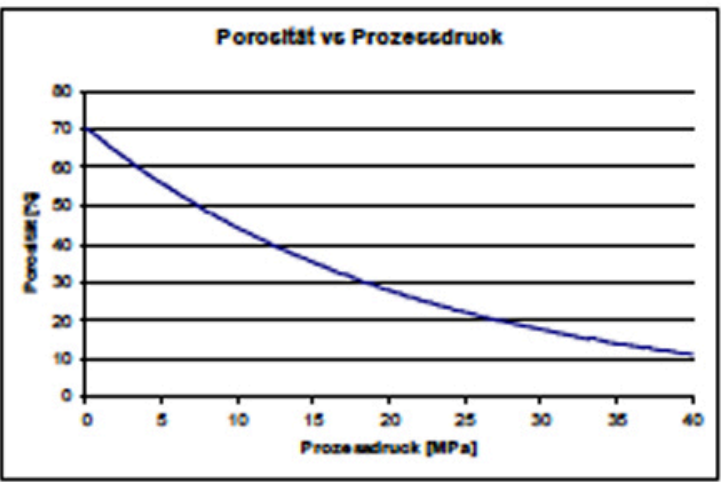

Porosity v8. Process pressure 


\section{Heraeus}

Electrical and thermal conductivity

(source VDI Verlag. Autor Mertens)

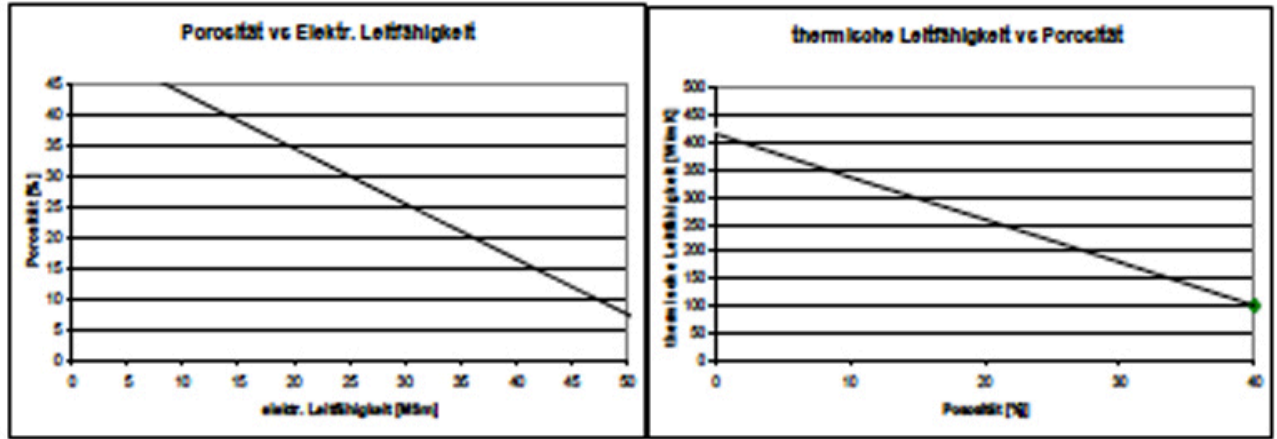

\section{Packaging}

Avallable in jars

50,150 und $250 \mathrm{~g}$

On request in cartridges

\section{Storability}

- Keep in jars

- Mn. 6 month at $2-10^{\circ} \mathrm{C}$

- Before using the paste must be homogenized

- Min. 3 month at $20-25^{\circ} \mathrm{C}$.

\begin{tabular}{|c|c|c|}
\hline 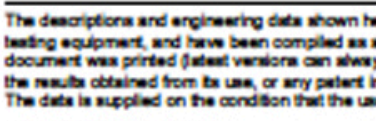 & 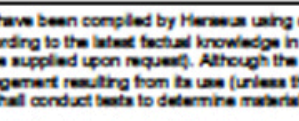 & 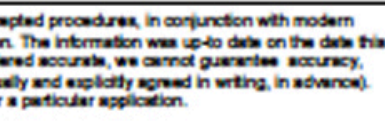 \\
\hline $\begin{array}{l}\text { Production Loostione } \\
\text { Europe }\end{array}$ & Amorlosc & Acla \\
\hline 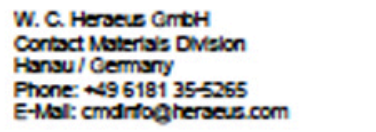 & 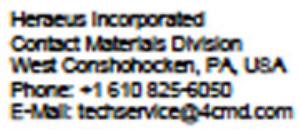 & 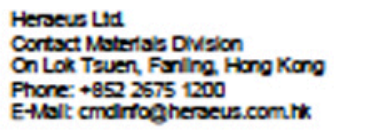 \\
\hline 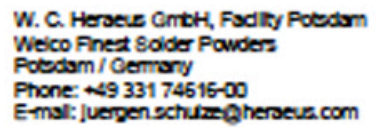 & Web: www. $4 \mathrm{cmd} . c 0 \mathrm{~m}$ & 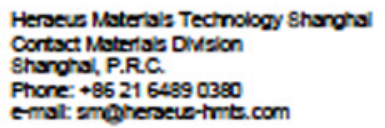 \\
\hline
\end{tabular}

05.05.2010 WS 